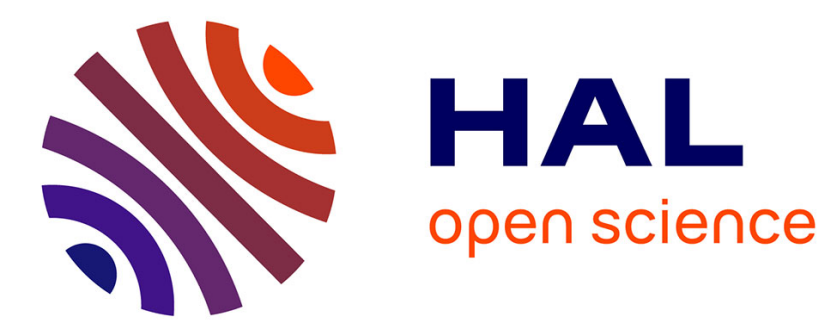

\title{
N2 in deep subsurface fracture fluids of the Canadian Shield: Source and possible recycling processes
}

Long Li, Kan Li, Thomas Giunta, Oliver Warr, Jabrane Labidi, Barbara

Sherwood Lollar

\section{- To cite this version:}

Long Li, Kan Li, Thomas Giunta, Oliver Warr, Jabrane Labidi, et al.. N2 in deep subsurface fracture fluids of the Canadian Shield: Source and possible recycling processes. Chemical Geology, 2021, 585, pp.120571. 10.1016/j.chemgeo.2021.120571 . hal-03390561

\section{HAL Id: hal-03390561 https://hal.science/hal-03390561}

Submitted on 21 Oct 2021

HAL is a multi-disciplinary open access archive for the deposit and dissemination of scientific research documents, whether they are published or not. The documents may come from teaching and research institutions in France or abroad, or from public or private research centers.
L'archive ouverte pluridisciplinaire HAL, est destinée au dépôt et à la diffusion de documents scientifiques de niveau recherche, publiés ou non, émanant des établissements d'enseignement et de recherche français ou étrangers, des laboratoires publics ou privés. 


\title{
$\mathbf{N}_{2}$ in deep subsurface fracture fluids of the Canadian Shield: Source and \\ possible recycling processes
}

2

3

4

5

6

7

\author{
Long $\mathrm{Li}^{1,2^{*}}$, Kan $\mathrm{Li}^{1}$, Thomas Giunta ${ }^{2,3}$, Oliver Warr ${ }^{2}$, Jabrane Labidi ${ }^{4}$, Barbara Sherwood \\ Lollar $^{2}$
}

1. Department of Earth and Atmospheric Sciences, University of Alberta, Edmonton, Alberta, Canada

2. Department of Earth Sciences, University of Toronto, Toronto, Ontario, Canada

3. IFREMER, Unité des Géosciences Marines, 29280 Plouzané, France

4. Université de Paris, Institut de Physique du Globe de Paris, Université Paris Diderot, 75005 Paris, France

* Corresponding author (email: long4@ualbertaca)

\section{Key Words}

Nitrogen cycle, Canadian Shield, deep subsurface, abiotic nitrogen reduction, microbial ammonium oxidation 
Abstract: In addition to high concentrations of $\mathrm{CH}_{4}$ and $\mathrm{H}_{2}$, abundant dissolved $\mathrm{N}_{2}$ is found in subsurface fracture fluids in Precambrian cratons around the world. These fracture fluids have hydrogeological isolation times on order of thousands to millions and even billions of years. Assessing the sources and sinks of $\mathrm{N}_{2}$ and related (bio)geochemical processes that drive the nitrogen cycle in these long isolated systems can shed insights into the nitrogen cycles on early Earth with implications for other planets and moons. In this study, we collected dissolved gas samples from deep subsurface fracture fluids at seven sites (Kidd Creek, LaRonde, Nickel Rim, Fraser, Copper Cliff South, Thompson, and Birchtree) in the Canadian Shield. Multiple gas components (e.g., $\mathrm{H}_{2}, \mathrm{O}_{2}$ and Ar) were integrated with $\delta^{15} \mathrm{~N}_{\mathrm{N} 2}$ values to characterize the $\mathrm{N}_{2}$ signatures. Results show that the dissolved $\mathrm{N}_{2}$ in deep subsurface fracture fluids from the Canadian Shield sites are more ${ }^{15} \mathrm{~N}$-enriched than those from the Fennoscandian Shield and the Witwatersrand Basin in the Kaapvaal Craton. The nitrogen isotopic signatures of the Canadian Shield samples coupled with their hydrogeological framework indicate the $\mathrm{N}_{2}$ was sourced from fixed ammonium in silicate minerals in host rocks and was generated by metamorphic devolatilization. Modeling of nitrogen devolatilization from host rocks supports this interpretation, but also suggests that a second process, likely abiotic $\mathrm{N}_{2}$ reduction, is required to account for the observed ${ }^{15} \mathrm{~N}$ enrichment in the $\mathrm{N}_{2}$ samples from the Canadian Shield. A 10-year monitoring study for one of the boreholes, at $2.4 \mathrm{~km}$ of the Kidd Creek Observatory, shows a steady decrease in $\delta^{15} \mathrm{~N}_{\mathrm{N} 2}$ values with time, which coincides with the temporal isotopic evolution of some other gas components in this borehole. Although it cannot be confirmed at this time, this isotopic shift in $\mathrm{N}_{2}$ may be potentially attributed to microbial processes (e.g., anaerobic oxidation of ammonium). Nevertheless, the large ${ }^{15} \mathrm{~N}$ enrichments for the majority of the samples in this study suggest that the nitrogen cycle in the deep saline fracture fluids in the Canadian Shield is dominated by abiotic processes. This is in contrast to the nitrogen cycles in the subsurface fracture fluids in the Fennoscandian Shield and the Witwatersrand Basin, which have been shown to be strongly affected by extant microbial ecosystems discovered in those fracture waters. 


\section{Introduction}

Precambrian cratons occupy the majority of the Earth's continental crust ( $>70 \%$ by surface area; Goodwin, 1996). These remnants of early Earth's crust are dominated by (meta-)igneous rocks varying from ultramafic to felsic in composition (e.g., Hoffmann, 1989). Abundant fractures developed over the history of these igneous rocks host a large terrestrial subsurface water reservoir of up to $30 \%$ of the planet's total groundwater inventory (Warr et al., 2018). Geochemical signatures (e.g., salinity, major and trace elemental compositions, dissolved gas contents, redox condition, $\delta^{18} \mathrm{O}$ and $\delta^{2} \mathrm{H}$ ) of these fluids indicate that they have been strongly influenced by water-rock reactions, and, in some cases, affected by mixing with varying amounts of secondary (paleo-)meteoric water (e.g., Ward et al., 2004; Onstott et al., 2006; Li et al., 2016; Heard et al., 2018; Warr et al., 2021a and references therein). Most of these deep subsurface fracture water systems have been hydrogeologically isolated over geological time scales, e.g., up to hundreds of million years to billions of years in the Canadian Shield (Holland et al., 2013; Warr et al., 2018), up to tens to hundreds of million years in the Fennoscandian Shield (Kietäväinen et al., 2014) and the Witwatersrand Basin in the Kaapvaal Craton, South Africa (Heard et al., 2018; Lippmann et al., 2003). Closed-system water-rock interactions over these extended time periods has progressively produced chemicals (e.g., $\mathrm{H}_{2}$, hydrocarbons, sulfate) and highly reducing habitable environments favorable for chemo(litho)trophic microbes (Lin et al., 2005, 2006; Li et al., 2016; Magnabosco et al., 2018; Lollar et al., 2019).

Studies of the subsurface fracture fluids from the Kaapvaal Craton, the Canadian Shield and the Fennoscandian Shield have identified some general quasi-depth-controlled variations in geochemistry and microbial community attributed to the degree of penetration of (paleo-)meteoric water into the subsurface (Warr et al;., 2021a and references therein). Based on 
noble gas studies, the shallower fracture fluids generally have shorter residence times, whereas the deeper, more saline fracture fluids have longer residence times (Lippmann et al., 2003; Lippmann-Pipke et al., 2011; Heard et al., 2018; Warr et al., 2018; 2021a). The shallow fracture fluids are mostly highly oxidizing fresh to brackish waters, and contain abundant biomass with diverse microbial communities; in contrast, the deep fracture fluids are mostly highly reducing saline to brine waters, and contain low-abundance biomass with less microbial diversity (e.g., Ward et al., 2004; Onstott et al., 2006; Lin et al., 2006; Magnabosco et al., 2015; Lollar et al., 2019).

These geochemical and microbiological differences can directly impact the isotopic signatures of the dissolved gaseous components in the fracture fluids. For example, different carbon recycling pathways have been clearly identified in these fracture fluids based on the carbon and hydrogen isotopic signatures of $\mathrm{CH}_{4}$ and other light n-alkanes (e.g., Sherwood Lollar et al., 1993a, b, 2002, 2006, 2008; Ward et al., 2004; Warr et al., 2021b) and clumped isotopic signatures of $\mathrm{CH}_{4}$ and $\mathrm{N}_{2}$ (Young et al., 2017; Labidi et al., 2020; Warr et al., 2021b). These studies have reported consistent observations from both the Canadian Shield and the Kaapvaal Craton suggesting that $\mathrm{CH}_{4}$ in the shallower fracture fluids is dominantly microbial, whereas $\mathrm{CH}_{4}$ in the deeper, more saline fracture fluids with longer residence times can show predominantly abiogenic signatures (Sherwood Lollar et al., 2006; 2008, 2021; Warr et al., 2021b;). More recently, formate and acetate in fluids at 2.4 to $3 \mathrm{~km}$ below surface (kmbs) at one of the key deep subsurface sites of the Canadian Shield, the Kidd Creek (KC) Observatory, have been demonstrated to be produced by abiotic organic synthesis (Sherwood Lollar et al., 2021). Multiple sulfur isotopic signatures of dissolved sulfate in fluids from $2.4 \mathrm{kmbs}$ of the $\mathrm{KC}$ 
Observatory also indicate that the dissolved sulfate in these fluids was derived from abiotic process by indirect radiolytic oxidation of sulfide minerals in host rocks (Li et al., 2016).

Despite numerous studies on the carbon and sulfur cycles in the subsurface fracture fluids in Precambrian cratons, to date, the cycle of another life-constituting element, nitrogen, has not been well examined, particularly in the Canadian Shield. $\mathrm{N}_{2}$ is typically the second largest dissolved gas component by volume in subsurface fracture fluids in Precambrian cratons around the world. In an earlier study, Sherwood Lollar et al. (1993a) reported the $\delta^{15} \mathrm{~N}$ values of $\mathrm{N}_{2}$ collected from fracture fluids in the Fennoscandian Shield and the Canadian Shield. Thirteen $\mathrm{N}_{2}$ samples from the Fennoscandian Shield show a $\delta^{15} \mathrm{~N}$ range from $0.2 \%$ to $5.1 \%$ (with one high value of $10.0 \%$ ), whereas four $\mathrm{N}_{2}$ samples from the Canadian Shield mostly show higher $\delta^{15} \mathrm{~N}$ values (Thompson: 1.4\%; Matagami: 8.6\%; Norita: 11.8\%o; Val d'Or: 9.1\%o). Labidi et al. (2020) also reported two $\delta^{15} \mathrm{~N}$ data from Sudbury (2.6\% and 2.8\%o) and two $\delta^{15} \mathrm{~N}$ data from the KC Observatory (6.6\%o and 6.8\%o). Dissolved $\mathrm{N}_{2}$ in subsurface fracture fluids from the Witwatersrand Basin in the Kaapvaal Craton was studied by Silver et al. (2012). After correction for air contamination using the $\mathrm{N}_{2} / \mathrm{O}_{2}$ ratio as an index, a $\delta^{15} \mathrm{~N}_{\mathrm{N} 2}$ range from $-1.3 \%$ to $5.8 \%$ was yielded and considered to result from complicated geochemical and, more importantly, biological recycling processes (Silver et al., 2012).

The relatively few $\delta^{15} \mathrm{~N}$ data from the Canadian Shield make it difficult to compare with those from the Fennoscandian Shield and the Kaapvaal Craton for the understanding of nitrogen cycle in subsurface fracture fluids in Precambrian cratons. In this context, it is important to carry out a more comprehensive investigation of $\mathrm{N}_{2}$ in deep fracture fluids in the Canadian Shield, particularly those from the KC Observatory. The KC Observatory located in Timmins (Ontario) is an iconic site for the study of subsurface fracture fluids, given the tremendous knowledge 
about this site accumulated from studies over nearly three decades (e.g., Sherwood Lollar et al., 1993a, b, 2002, 2021; Doig et al. 1995; Holland et al., 2013; Li et al., 2016; Lollar et al., 2019). In particular, long-term monitoring has been possible at an observatory location $2.4 \mathrm{kmbs}$ since 2007, commencing shortly after the exploratory boreholes were drilled. Noble gas studies indicate that the mean residence times of the fluids at $\mathrm{KC}$ were extremely long (e.g., $1.0-2.2 \mathrm{Ga}$ at $2.9 \mathrm{kmbs}$; Warr et al., 2018), while hydrogeological draining of the fluids may result in some boreholes decreasing in age over time (e.g., at $2.4 \mathrm{kmbs}$, initially $1.1-1.7 \mathrm{Ga}$ but has decreased to $0.2-0.6$ Ga recently; Holland et al., 2013, Warr et al., 2018). To date, these fluids show the presence of chemolithotrophic organisms (sulfate-reducing organisms in particular) but with low biomass and low rates of activity (Li et al., 2016; Lollar et al., 2019; Sherwood Lollar et al., 2021; Warr et al., 2021b). The geochemical and isotopic signatures of these fluids (including dissolved components) may represent the closest abiotic end-members available in the terrestrial deep subsurface (e.g., Sherwood Lollar et al., 2021; Warr et al., 2021b). Such abiotically dominated sites provide a valuable opportunity to assess the long-term abiotic nitrogen recycling processes occurring in these highly reducing waters. This knowledge may further provide crucial insights into the geochemical processes that could have influenced the origin and early evolution of life on the early Earth, and inform models of possible habitability on other planets and moons (NASEM, 2019).

Here we report the gas concentrations and $\delta^{15} \mathrm{~N}_{\mathrm{N} 2}$ values of 45 samples from 7 sites in the Canadian Shield (Fig. 1). In particular, 25 samples were collected from the KC Observatory from 2.1 to $2.9 \mathrm{kmbs}$, and at the $2.4 \mathrm{kmbs}$ sampling location, over a temporal span of 10 years (20072017). This sample suite provides a high-density dataset to evaluate the spatial and temporal changes of the nitrogen cycle in these fracture water systems. Aiming to better constrain the 
nitrogen source and recycling processes in the fracture fluids in the Canadian Shield, bulk-rock nitrogen concentrations and isotope compositions were also analyzed on 23 host rock samples from KC, Sudbury, and Thompson. For comparison, nitrogen isotope compositions were also measured on refractory carbon component in 6 graphite-bearing samples from KC.

\section{Geological background and samples}

The samples in this study were collected from two sites in the Abitibi greenstone belt (i.e., $\mathrm{KC}$ and LaRonde), three sites in the Sudbury Basin (i.e., Copper Cliff South, Nickel Rim, and Fraser), and two neighboring sites (Birchtree and Thompson) in the Thompson nickel belt in the western Superior boundary zone, near Thompson, Manitoba (Fig. 1).

The KC Observatory in Ontario is geologically located in the volcanic successions of the Kidd-Munro assemblage in the Abitibi. The host rocks at KC include 2.71 - 2.72 Ga ultramafic, mafic (gabbros and basalts) to felsic (mainly rhyolites) rocks with graphite-bearing lenses formed in a rifting sub-proximal seafloor setting (Bleeker and Parrish, 1996; Hannington et al., 1999; Prior et al., 1999). The rocks experienced regional metamorphism which started at 2.69 $\mathrm{Ga}$, reached peak metamorphism of greenschist facies $\left(\sim 400^{\circ} \mathrm{C}\right)$ at $2.64 \mathrm{Ga}$, and ended as late as 2.60 Ga locally (Barrie and Davis, 1990; Smith et al., 1993; Davis et al., 1994; Bleeker et al., 1999; Powell et al., 2011).

LaRonde (LR) in Quebec is geologically located in the Bousquet formation of the $2.7 \mathrm{Ga}$ Blake River group in the Abitibi. The host rocks are composed of a continuous magmatic series of tholeiitic - transitional mafic to felsic rocks in the lower member, and transitional - calcalkaline intermediate to felsic rock in the upper member (Mercier-Langevin et al., 2007). The 
rocks experienced a prograde metamorphism to upper greenschist - lower amphibolite facies and a subsequent greenschist-facies retrograde metamorphism (Dimroth et al., 1983).

Copper Cliff South (CCS), Nickel Rim (NR) and Fraser (FR) are all in the Sudbury impact basin (Ontario). The dominant rock assemblage in the region is the Sudbury Impact Complex (SIC) which was formed by meteoritic impact-induced melting of the Archean basement (Faggart et al., 1985) in 1.85 Ga (Krogh et al., 1982; Davis, 2008). FR is in the middle of the North Range and NR is in the east of the South Range of the SIC. Both sites geologically lie in the footwall of the SIC that is dominated by 2.64 Ga granitic rocks (Meldrum et al., 1997) and Archean meta-volcanic and metasedimentary rocks that were metamorphosed to upper greenschist - lower amphibolite facies at $2.69 \mathrm{Ga}$ with some reaching granulite facies at 2.65 Ga (Krogh et al., 1984). CCS is located in a radial offset quartz-diorite dyke in the South Range with brecciated country rocks and abundant sulfide mineralization (Lightfoot and Farrow, 2002) related to the $\sim 1.85$ Ga bolide impact. Post-impact thermal influences by multiple orogenies, such as the Yavapai-Mazatzal (1.7-1.6 Ga), the Chieflakian-Pinwarian (1.5-1.4 Ga) and the Grenville (1.2-1.0 Ga), have been found at various degrees across the Sudbury region, e.g., mid- to upper-greenschist facies in the South Range (Fleet et al., 1987) and sub-greenschist facies $\left(<150^{\circ} \mathrm{C}\right)$ in the North Range (Thompson et al., 1998).

The Thompson nickel belt (near Thompson, Manitoba) is a northeast-southwest trending belt formed in an early Proterozoic continental margin. It is constituted by reworked Archean basement and meta-supracrustal rocks (Hulbert et al., 2005). In the western part of the belt where BT and TH are located, the rocks are dominated by $2.2-2.0$ Ga serpentinized ultramafic rocks, metagabbros, amphibolites, gneisses, schists, skarns, and quartzites (Hulbert et al., 2005; 
Zwanzig et al., 2007). The rocks experienced a series of metamorphic events during $1850-1750$

Ma (Couëslan et al., 2013) with peak metamorphic temperatures of $\sim 700{ }^{\circ} \mathrm{C}$ in the Thompson area (Paktunç, 1984). Later (not yet dated) low-temperature $\left(250-300{ }^{\circ} \mathrm{C}\right)$ alteration of rocks at Thompson by chloride-rich fluid is evidenced by the PGE-Au-As mineralization (Chen et al., 1993).

Gas samples were collected following the method described by Ward et al. (2004) and Holland et al. (2013). In brief, a packer was used to seal the borehole and funnel the water and gas flow from the borehole through a sterilized Tygon tube into a bucket. After a period of flushing to ensure representative sampling, gases were introduced into an inverted beaker submerged into the fracture fluids collected in a bucket. The gases were then transferred through a 22-g syringe needle on a Luer attachment at the top of the beaker into $160 \mathrm{ml}$ borosilicate vials with blue butyl stoppers which had been sterilized, prefixed with $50 \mu \mathrm{L}$ saturated $\mathrm{HgCl}_{2}$ solution, and pre-evacuated.

Rocks samples were collected from exploration drill cores provided by the mines. A total of 23 samples were selected from representative lithologies of the host rocks from KC, Sudbury, and Thompson.

\section{Methods}

Gas concentrations and nitrogen isotope compositions of $\mathrm{N}_{2}$ were analyzed at University of Toronto. Gas concentrations were generally measured within days after sample collection to avoid possible shifts in gas (e.g., $\mathrm{H}_{2}$ and $\mathrm{O}_{2}$ ) concentrations due to diffusion and/or reaction, although the results of re-analyses in 2007 on a batch of samples collected in 2000 show no 
significant difference in $\mathrm{H}_{2}$ and $\mathrm{O}_{2}$ concentrations in comparison with the results obtained in 2000. Gas concentrations were measured by a Varian gas chromatography equipped with Varian Molecular Sieve 5A PLOT fused silica column and a micro-thermal conductivity detector ( $\mu$ TCD) for $\mathrm{H}_{2}, \mathrm{He}, \mathrm{N}_{2}, \mathrm{CO}_{2}, \mathrm{O}_{2}, \mathrm{Ar}$ and a flame ionization detector for alkanes following the published protocols (e.g., Ward et al., 2004). $\mathrm{NH}_{3}$ is not specially examined here because it requires high $\mathrm{pH}$ condition to drive $\mathrm{NH}_{3}$ from fluids to gas phases (e.g., Deng et al., 2018), whereas the modeling based on the $\mathrm{pH}$ and temperature conditions of the studied fluid samples suggests that $\mathrm{NH}_{3}$ mostly concentrates in fluids and barely occurs in the gas phases (Li et al., 2012). The $2 \sigma$ analytical error is $<5 \%$ of the absolute concentrations based on repeated analyses of lab standards and natural samples. The nitrogen isotopic ratio of $\mathrm{N}_{2}$ was measured by gas chromatography-isotope ratio mass spectrometry. An aliquot of a gas sample was taken by gastight syringe from a sample bottle and injected into a Varian gas chromatography, in which a slow flow rate of $1.2 \mathrm{ml} / \mathrm{min}$ was used for the carrier gas (ultrahigh-purity helium) to ensure the separation of $\mathrm{N}_{2}$ from other gas components such as $\mathrm{H}_{2}$ and $\mathrm{O}_{2} \cdot \mathrm{CO}_{2}$ and $\mathrm{CO}$ are not significant interferences in this analysis because their natural abundances in the gas samples are below the detection limit $(<0.01 \mathrm{vol} \%)$. A time window was set to allow $\mathrm{N}_{2}$ but no other interference gases to be carried into a Finnigan 252 isotope ratio mass spectrometer for isotopic measurements. The isotopic ratios are reported using the $\delta$ notation $\left(\delta^{15} \mathrm{~N}=\left({ }^{15} \mathrm{~N} /{ }^{14} \mathrm{~N}\right)_{\text {sample }}\left({ }^{15} \mathrm{~N} /{ }^{14} \mathrm{~N}\right)_{\text {standard }}-1\right)$, in which "standard" is atmospheric $\mathrm{N}_{2}$. All samples were measured in duplicate. Repeat analyses of these samples and laboratory working standards cross-calibrated against international IAEA nitrogen reference materials gave $2 \sigma$ analytical errors better than $0.2 \%$.

Nitrogen isotopic ratios of rocks were measured at University of Alberta following the method described by Li et al. (2021a). In brief, after removal of the surface by sawing, rock 
chips from drill cores were ground into fine powders ( $<200 \mathrm{mesh})$. For the graphite-bearing lens samples, nitrogen was measured on both bulk-rock samples and refractory reduced carbon residues following the extraction protocol of Eigenbrode and Freeman (2006). The powder samples were weighted and loaded into pre-cleaned one end-sealed quartz tube together with $\mathrm{CuO}$ reagents, pumped in a metal manifold, sealed under high vacuum, and combusted first at $1200{ }^{\circ} \mathrm{C}$ for $30 \mathrm{~min}$ to $60 \mathrm{~min}$ (depending on lithology; see details in Li et al., 2021a) and then at $900{ }^{\circ} \mathrm{C}$ overnight to completely release the fixed nitrogen in minerals. The sample tube was then cracked under high vacuum to release $\mathrm{N}_{2}$, which was further cryogenically purified, quantified by a capacitance manometer, and carried by an ultrahigh-purity helium gas to a Thermo Finnigan MAT 253 for nitrogen isotopic measurements. The $\delta^{15} \mathrm{~N}$ values are reported relative to the atmospheric $\mathrm{N}_{2}$. Repeat analyses of two standards (Low Organic Content Soil and High Organic Content Soil) from Elemental Microanalysis Ltd gave $2 \sigma$ analytical errors better than $0.2 \%$ ( $\mathrm{Li}$ et al., 2021a).

\section{Results}

\subsection{Gas concentrations and $\delta^{15} \mathrm{~N}_{\mathrm{N} 2}$ values}

The major gas concentrations and $\delta^{15} \mathrm{~N}$ values of $\mathrm{N}_{2}$ are reported in Table 1 . The results are briefly summarized below.

Twenty-five gas samples from $\mathrm{KC}$ are dominated by $\mathrm{CH}_{4}(64-83$ vol\%) and other light n-alkanes (e.g., ethane, propane, butane; in total $<9$ vol\%). $\mathrm{N}_{2}$ is the second most abundant gas component with concentrations varying from $4.5 \mathrm{vol} \%$ to $16.9 \mathrm{vol} \%$ and $\delta^{15} \mathrm{~N}$ values from $3.2 \%$ to $8.0 \%$ (Table 1). These isotopic values fall in the $\delta^{15} \mathrm{~N}$ range of $2.8 \%-8.8 \%$ from a limited 
set of KC samples in Montgomery (1994) and Labidi et al. (2020). $\mathrm{H}_{2}$ gas was detected in all KC samples except one, with variable concentrations from 0.3 vol\% to 10.7 vol\%.

Two gas samples from LR are also dominated by $\mathrm{CH}_{4}\left(66-72\right.$ vol\%) and $\mathrm{N}_{2}(9-15$ vol\%) with $\delta^{15} \mathrm{~N}$ values of $6.5 \%$ and $7.4 \%$, respectively. Both samples contain $\mathrm{H}_{2}$ (1.8 vol\% and $3.6 \mathrm{vol} \%$, respectively). All these features are similar to those of the $\mathrm{KC}$ samples.

Six gas samples from CCS (on the south rim of the Sudbury Basin) are characterized by extremely high $\mathrm{H}_{2}$ concentrations $(10-58 \mathrm{vol} \%) . \mathrm{CH}_{4}$ is the other major gas component in these samples $(14-70 \mathrm{vol} \%)$. $\mathrm{N}_{2}$ concentrations are generally low in the samples studied at this site (Table 1). The $\delta^{15} \mathrm{~N}_{\mathrm{N} 2}$ values ( $(0.6 \%$ to $4.2 \%$ ) of these samples are also much lower than those of the $\mathrm{KC}$ and LR samples. It is worth noting that variable amounts of $\mathrm{O}_{2}(0.4-5.5 \mathrm{vol} \%)$ are detected in these samples, which suggests significant air contamination (see Section 4.2). In a previous unpublished study by Montgomery (1994), much higher $\mathrm{N}_{2}$ concentrations of up to 65 vol $\%$ and $\delta^{15} \mathrm{~N}$ values up to $17.5 \%$ were reported from CCS. The other samples from the Sudbury Basin show significantly higher $\mathrm{N}_{2}$ concentrations. The five NR gas samples are dominated by $\mathrm{N}_{2}\left(47-53\right.$ vol\%), $\mathrm{He}\left(24-32\right.$ vol\%) and $\mathrm{CH}_{4}\left(15-24\right.$ vol\%). $\mathrm{H}_{2}$ occurs all samples in varying amounts $\left(0.01-2.7\right.$ vol\%). The $\delta^{15} \mathrm{~N}_{\mathrm{N} 2}$ values display a small range from $3.5 \%$ to $5.0 \%$. The only gas sample available from FR is also dominated by $\mathrm{N}_{2}(66 \mathrm{vol} \%), \mathrm{He}$ (17 vol\%) and $\mathrm{CH}_{4}(20 \mathrm{vol} \%)$. It also contains much higher Ar concentration (5.2 vol\%) than all the other studied gas samples from the Canadian Shield ( $<2$ vol\%). The reason for this is not fully understood at this time. The FR sample has a $\delta^{15} \mathrm{~N}_{\mathrm{N} 2}$ value of $5.0 \%$, similar to those of the NR samples. 
$\mathrm{N}_{2}$. The $\mathrm{CH}_{4}$ concentrations $(63-69 \mathrm{vol} \%)$ are higher than $\mathrm{N}_{2}$ concentrations $(29-31 \mathrm{vol} \%)$ in the BT samples, whereas the $\mathrm{N}_{2}$ concentrations (46-66 vol\%) are higher than the $\mathrm{CH}_{4}$ concentrations (35- 48 vol\%) in the TH samples. Despite the difference in $\mathrm{N}_{2}$ concentration, the $\delta^{15} \mathrm{~N}_{\mathrm{N} 2}$ values are consistent between BT and TH, ranging from 7.4\% to 8.7\% . All of the BT and TH gas samples except one contain detectable $\mathrm{H}_{2}$, generally at levels between $0.02-2.75$ vol\%.

\subsection{Distinguishing sampling-related air contamination}

A characteristic feature of the studied gas samples from the Canadian Shield is the ubiquitous occurrence of $\mathrm{H}_{2}$ gas (Table 1). This indicates that highly reducing conditions have been established and maintained in the host fracture fluids of these gas samples, which is consistent with all past studies. These highly reduced fracture fluids should not contain any insitu $\mathrm{O}_{2}$ gas (Holland et al., 2013; Warr et al; 2018, 2021a). Therefore, any $\mathrm{O}_{2}$ detected in the gas samples should be indicative of recent air contamination, mostly likely during sampling.

To assess the air contamination in the studied samples, $\delta^{15} \mathrm{~N}_{\mathrm{N} 2}$ values are compared with $\mathrm{N}_{2} / \mathrm{O}_{2}$ and $\mathrm{N}_{2} / \mathrm{Ar}$ concentration ratios (Fig. 2). Fig. 2A illustrates a decreasing trend of $\delta^{15} \mathrm{~N}_{\mathrm{N} 2}$ values following the decrease in $\mathrm{N}_{2} / \mathrm{O}_{2}$ ratios toward the air end-member, particularly seen in some of the CCS and KC samples. The data comparison (Fig. 2A) shows that more consistent ranges of $\delta^{15} \mathrm{~N}_{\mathrm{N} 2}$ values can be observed for samples with $\mathrm{N}_{2} / \mathrm{O}_{2}$ ratios $>15$ at each site. The $\delta^{15} \mathrm{~N}_{\mathrm{N} 2}$ values of samples with $\mathrm{N}_{2} / \mathrm{O}_{2}<15$ are more or less altered by air contamination.

Unlike $\mathrm{O}_{2}$, which can be readily identified as a result of air contamination in these highly reducing fluids, ${ }^{40} \mathrm{Ar}$ (the dominant isotope of Ar) can be produced by subsurface processes and hence cannot be used to evaluate air contamination (Fig. 2B). ${ }^{40} \mathrm{Ar}$, a product of the radioactive 
decay of ${ }^{40} \mathrm{~K}$, can accumulate in the fracture waters over time and vary significantly depending on the lithology of local host rocks and isolation time of the fracture fluids (Warr et al., 2019). $\mathrm{N}_{2}$ concentrations may also vary significantly, depending on the thermal history, nitrogen source, abiotic reactions, and biological activities (if any) in the fracture waters (Silver et al., 2012). These two factors can result in highly heterogeneous $\mathrm{N}_{2} / \mathrm{Ar}$ ratios in the deep subsurface of the Canadian Shield (Fig. 2B), which may be a result of $i$-situ processes and not necessarily reflect air contamination. The data compilation of less contaminated samples (i.e., $\mathrm{N}_{2} / \mathrm{O}_{2}>15$ ) on Fig. $2 \mathrm{C}$ illustrates that the $\mathrm{N}_{2} / \mathrm{Ar}$ ratios increase in order from LR, FR, NR, KC, to BT and TH. Therefore, without knowing the $\mathrm{N}_{2} / \mathrm{Ar}$ values of uncontaminated gases, $\mathrm{N}_{2} / \mathrm{Ar}$ ratios alone cannot be used to estimate the fractions of air components in gas samples from Precambrian cratons. Accordingly, the discussion below on the $\delta^{15} \mathrm{~N}_{\mathrm{N} 2}$ values of the Canadian Shield samples will focus only on those with $\mathrm{N}_{2} / \mathrm{O}_{2}>15$.

\section{3. $\delta^{15} \mathrm{~N}$ values of rock samples}

The nitrogen concentrations and $\delta^{15} \mathrm{~N}$ values of rock samples are listed in Table 2.

Six silicate host rock samples from $\mathrm{KC}$, including three rhyolites, two silicified cherty breccia and one quartz feldspar porphyry, show a $\delta^{15} \mathrm{~N}$ range from $6.0 \%$ to $10.4 \%$. Six samples of the graphite-bearing lenses from $\mathrm{KC}$ give a $\delta^{15} \mathrm{~N}$ range from $6.7 \%$ to $15.6 \%$ for bulk-rock nitrogen, but a lower $\delta^{15} \mathrm{~N}$ range from $0.4 \%$ to $10.4 \%$ for extracted refractory reduced carbon residues.

Sudbury host rock samples comprise of two samples (a meta-gabbro and a breccia matrix) from the Creighton mine, which has similar wall rock to the CCS mine, and six samples from NR (two felsic gneisses, two felsic norites, one granodiorite, and one breccia). All the 
samples give a small $\delta^{15} \mathrm{~N}$ range from $1.3 \%$ to $3.4 \%$ except one felsic norite sample with a $\delta^{15} \mathrm{~N}$ value of $-5.6 \%$.

Three host rock samples from TH, inducing one gneiss, one schist, and one skarn, show relatively high $\delta^{15} \mathrm{~N}$ values from $7.0 \%$ to $10.2 \%$.

\section{Discussion}

\section{1. $\delta^{15} \mathbf{N}_{N 2}$ variability across sites in the Canadian Shield}

After discarding all the samples with $\mathrm{N}_{2} / \mathrm{O}_{2}<15$, the $\delta^{15} \mathrm{~N}_{\mathrm{N} 2}$ distribution (Fig. 2C) shows a general trend with the lowest values in NR and FR, and steadily increasing values from LR, $\mathrm{KC}$, to $\mathrm{BT}$ and $\mathrm{TH}$. However, this isotopic pattern is not confirmative at the moment given that only a small number of samples were collected from a specific depth in each of the sites (except $\mathrm{KC)}$. A larger dataset from multiple depths at $\mathrm{KC}$ give much larger $\delta^{15} \mathrm{~N}_{\mathrm{N} 2}$ variation than those of the other sites (Fig. 2C; see Section 5.4 for discussion). Two samples from different depths at CCS also show large $\delta^{15} \mathrm{~N}_{\mathrm{N} 2}$ variation (Montgomery, 1994; Fig. 2A). Therefore, more data from each site are needed in future studies to examine the inter-site $\delta^{15} \mathrm{~N}_{\mathrm{N} 2}$ variability and its controlling factors in the Canadian Shield.

\subsection{Comparison with the Fennoscandian Shield and the Kaapvaal Craton}

The $\delta^{15} \mathrm{~N}$ values of $\mathrm{N}_{2}$ from subsurface fracture fluids have been reported from some sites on other Precambrian cratons, e.g., the Fennoscandian Shield (Sherwood Lollar et al., 1993a) and the Kaapvaal Craton (Silver et al., 2012). As mentioned above, the thirteen published gas samples from the Fennoscandian Shield (Sherwood Lollar et al., 1993a) have $\delta^{15} \mathrm{~N}_{\mathrm{N} 2}$ values from $0.2 \%$ to $5.1 \%$ (except one high value of $10.0 \%$ ) with a peak at the bin of $0-1 \%$ (Fig. 3A). Silver 
et al. (2012) reported the $\delta^{15} \mathrm{~N}_{\mathrm{N} 2}$ values of eighteen gas samples from Beatrix (BE116, 325, 327), Driefontein (Dr938), Evander (EV219, 522, 818), Kloof (KL441, 739), Masimong (MM5), Merriespruit (MS151), Mponeng (MP104) in the Witwatersrand Basin in the Kaapvaal Craton. These fracture systems have mean residence times varying from $0.7 \mathrm{Ma}$ (EV522) to $20 \mathrm{Ma}$ (KL739 and MP104) with one sample (Dr938) having a ${ }^{14} \mathrm{C}$-derived age of 1022 years (Lippmann et al., 2003; Lin et al., 2006; Silver et al., 2012 and reference therein). The hydrogen and oxygen isotope compositions of these fracture fluids spread from on (or close to) the global meteoric water line (GMWL) to above the GMWL (Lippmann et al., 2003; Ward et al., 2004; Lin et al., 2006; Onstott et al., 2006; Warr et al., 2021a). Their $\delta^{15} \mathrm{~N}_{\mathrm{N} 2}$ values fall in the range of $-1.3 \%$ to $5.8 \%$ (Fig. $3 \mathrm{~B}$ ). The $\delta^{15} \mathrm{~N}_{\mathrm{N} 2}$ values do not correlate with either the residence times or the magnitude of isotopic deviation above the GMWL, indicating the major control on the $\delta^{15} \mathrm{~N}_{\mathrm{N} 2}$ values of the samples in the Kaapvaal Craton may not be geological processes (e.g., fluid-rock interaction) but biological processes.

In contrast, the Canadian Shield samples show consistently higher $\delta^{15} \mathrm{~N}_{\mathrm{N} 2}$ values (Fig. 3C). A total of thirty-five samples studied here cluster in a $\delta^{15} \mathrm{~N}_{\mathrm{N} 2}$ range of $3.0 \%$ to $8.0 \%$ with a peak at the bin of 7-8\% (Fig. 3C), while three historical samples from Montgomery (1994) and Sherwood Lollar (1993a) give more variable $\delta^{15} \mathrm{~N}_{\mathrm{N} 2}$ values of $1.4 \%$, $1.5 \%$ and $17.5 \%$, respectively (Fig. 2A). The $\delta^{15} \mathrm{~N}_{\mathrm{N} 2}$ discrepancy between the Canadian Shield samples and the samples from the Fennoscandian Shield and the Kaapvaal Craton could be attributed to the differences in nitrogen source and abiotic and biological processes among these deep subsurface fracture waters, which are discussed in detail below.

\subsection{Source of $\mathrm{N}_{2}$ in the Canadian Shield}


Several sources could potentially contribute to the $\mathrm{N}_{2}$ in the terrestrial subsurface fracture

water systems, such as ancient atmospheric $\mathrm{N}_{2}$, dissolved inorganic nitrogen species (nitrate, nitrite, ammonium) in pore water and/or fluid inclusions in host rocks, and fixed nitrogen in host rocks.

In the studied samples from the Canadian Shield, although noble gas studies imply that these fracture fluids contain a minor initial component of noble gas (e.g., Xe) derived from ancient air (Holland et al., 2013; Warr et al., 2018), a ballpark estimation based on the concentration data of gases and rocks in Li et al. (2016) and typical $\mathrm{N}_{2}$ concentration of seawater (Kipfer et al., 2002) suggests that the ancient air contributed at most $0.1-6 \%$ of the gas components. Therefore, ancient atmospheric $\mathrm{N}_{2}$ can be excluded as the main source. In addition, a recent study discovered extreme ${ }^{15} \mathrm{~N}^{15} \mathrm{~N}$ enrichment of atmospheric $\mathrm{N}_{2}$ (Yeung et al., 2017). Assuming the ancient atmospheric $\mathrm{N}_{2}$ had comparable ${ }^{15} \mathrm{~N}^{15} \mathrm{~N}$ enrichment, and little re-ordering of the internal bonding of $\mathrm{N}_{2}$ molecules in these low-temperature fracture systems, a ${ }^{15} \mathrm{~N}^{15} \mathrm{~N}$ enrichment would be expected if significant amount of ancient atmospheric $\mathrm{N}_{2}$ contributed to the fluids. However, Labidi et al. (2020) found no ${ }^{15} \mathrm{~N}^{15} \mathrm{~N}$ enrichment in the KC samples. This suggests that the amounts of atmospheric $\mathrm{N}_{2}$, from both ancient air and modern air contamination, are relatively small in the total $\mathrm{N}_{2}$ of the samples.

Dissolved inorganic nitrogen species in pore water and fluid inclusions in host rock have been proposed to account for the abundant nitrate, $\mathrm{N}_{2}$ and ammonium in the subsurface fracture waters in the Witwatersrand Basin in the Kaapvaal Craton, South Africa (Silver et al., 2012). In this model, it requires (1) a high $\mathrm{NH}_{3}-\mathrm{NH}_{4}{ }^{+}$pool in fluid inclusions in the first place, (2) efficient migration of nitrogen in fluid inclusions to fracture fluids, and (3) abiotic and biological recycling processes to convert $\mathrm{NH}_{3} / \mathrm{NH}_{4}{ }^{+}$to other nitrogen species (e.g., $\mathrm{N}_{2}$ in this case). These 
conditions are relatively difficult to reach in the Canadian Shield where the igneous-rock dominated host rocks contain small volumes of primary fluid inclusions. Furthermore, geochemical and hydrogeological analyses have shown that contribution of young surface fluids is little in these fracture systems (e.g., Warr et al., 2021a), ruling out later infiltration of dissolved inorganic nitrogen from surface.

Sedimentary rocks are a commonly considered source for $\mathrm{N}_{2}$ in basinal environments. However, in the Canadian Shield, host rocks are dominated by crystalline rocks. At KC where host rock lithology has been well characterized from drill cores, graphite-bearing lenses occupy a very small volume in host rocks. The nitrogen concentrations of the graphite-bearing lenses (4099 ppm; Table 2) are significantly smaller than those of typical deep-sea sediments and their metamorphosed equivalents (hundreds to thousands of ppm; e.g., Bebout and Fogel, 1992; Busigny et al., 2003; Sadofsky and Bebout, 2004; Li and Bebout, 2005). Therefore, the graphitebearing lenses can less likely account for the widely occurring gases in the highly confined and locally controlled fracture water compartments (Warr et al., 2018). This conclusion is further supported by the carbon and hydrogen isotopic signatures of n-alkanes in the gas samples. The $\delta^{13} \mathrm{C}$ and $\delta^{2} \mathrm{H}$ patterns of n-alkanes are very different to that of conventional thermogenic gases (Sherwood Lollar et al., 1993b, 2002, 2008; Warr et al., 2021b). Overall, both isotopic fingerprints and hydrogeological frameworks do not favor organics as the main source of the gases.

Significant amounts of nitrogen (in form of ammonium) can be assimilated into the crystal structures of secondary phyllosilicate minerals (e.g., clay and serpentine) formed during the alteration of igneous rocks by seawater and/or hydrothermal fluids (Busigny et al., 2005; Li 
et al., 2007). The nitrogen measurement on six representative silicate samples from KC give a nitrogen concentration range from $12 \mathrm{ppm}$ to $34 \mathrm{ppm}$ (average: $\sim 24 \mathrm{ppm}$; Table 2) and a $\delta^{15} \mathrm{~N}$ range from $6.0 \%$ to $10.3 \%$ (average: $8.0 \%$ ). Given the large volume of the silicate host rocks in Precambrian cratons, such high nitrogen concentrations of the igneous host rocks represent a huge nitrogen reservoir, with an inventory orders in magnitude higher than that in the small volume of fluids. Mobilization by devolatilization of a small proportion of this reservoir is able to account for the $\mathrm{N}_{2}$ in the subsurface fracture waters.

To devolatilize the ammonium fixed in the igneous host rocks, it requires relatively high temperatures. In light of previous laboratory and field studies (e.g., Haendel et al., 1986; Bebout and Fogel, 1992), nitrogen devolatilization from minerals and rocks could have easily taken place under the peak (and retrograde) metamorphic conditions in the study sites, e.g., $400{ }^{\circ} \mathrm{C}$ at $\mathrm{KC}, 700{ }^{\circ} \mathrm{C}$ at $\mathrm{TH}$, and variable temperatures (depending on the distance to the crater; Abramov and Kring, 2004) during the impact event at Sudbury. At crustal conditions, high temperatures facilitate $\mathrm{N}_{2}$ as the devolatilization product (e.g., Bebout and Fogel, 1992; Li et al., 2009). The lower temperature limit for $\mathrm{N}_{2}$ devolatilization from minerals and rocks is however unconstrained. Even taking the smectite-illite transition temperature of $60{ }^{\circ} \mathrm{C}$ (Freed and Peacor, 1989) as the lower limit, it is still higher than the current temperatures of the studied fracture fluid systems. In particular, the Canadian Shield has been relatively stable and maintained a low thermal gradient since at least 2 Ga (Slack, 1974). Temperature estimation using the method of Li et al. (2016) suggests that the temperature at $\mathrm{KC}$ should have been $<60^{\circ} \mathrm{C}$ since at latest 1.3 Ga for the $2.1 \mathrm{kmbs}$ site and $0.9 \mathrm{Ga}$ for the $2.9 \mathrm{kmbs}$ site. Therefore, the observed $\mathrm{N}_{2}$ was mostly likely produced during earlier time periods. $\mathrm{N}_{2}$ production would have been most efficient during the peak metamorphism at each site, and diminish exponentially with the decrease in temperature 
with time. Given that the analyzed host rocks consistently show high nitrogen concentrations (Table 2), it only requires a very small (almost negligible) fraction of the total nitrogen in the rocks to account for the observed $\mathrm{N}_{2}$ in the fluids, which can be easily satisfied.

\subsection{Possible $\mathrm{N}$ recycling processes in subsurface fracture fluids}

\subsubsection{Abiotic $\mathrm{N}_{2}$ reduction}

Based on above discussions, the $\mathrm{N}_{2}$ in the deep subsurface fracture fluids in the Canadian Shield most likely originated by devolatilization of fixed ammonium in their silicate host rocks. Nitrogen devolatilization from rocks is associated with an isotopic effect with preferential uptake of ${ }^{14} \mathrm{~N}$ by $\mathrm{N}_{2}$ and preferential retention of ${ }^{15} \mathrm{~N}$ in host rock (e.g., Bebout and Fogel, 1992; Haendel et al., 1986; Li et al., 2021b, c). The magnitude of ${ }^{15} \mathrm{~N}$ depletion in the $\mathrm{N}_{2}$ product is dependent on two factors, i.e., the temperature-dependent isotope fractionation factor and the fraction of ammonium in rock that is converted into $\mathrm{N}_{2}$. The nitrogen isotope fractionation factors between $\mathrm{N}_{2}$ and clay minerals can be derived from Li et al. $(2021 \mathrm{~b}$, c) to be $-13.2 \%$ at 60 ${ }^{\circ} \mathrm{C},-10.9 \%$ at $100{ }^{\circ} \mathrm{C},-6.2 \%$ at $200{ }^{\circ} \mathrm{C},-4.1 \%$ at $400{ }^{\circ} \mathrm{C},-2.3 \%$ at $700{ }^{\circ} \mathrm{C}$ and $-1.5 \%$ at 1000

${ }^{\circ} \mathrm{C}$. Based on these fractionation factors, the theoretical $\delta^{15} \mathrm{~N}$ differences between $\mathrm{N}_{2}$ product and remaining ammonium in host rocks along the progress of metamorphic devolatilization are illustrated by a Rayleigh fractionation model in Fig. 4A-C for KC, Sudbury and Thompson, respectively. Comparison of average $\delta^{15} \mathrm{~N}$ values between $\mathrm{N}_{2}$ and host rocks yield $\Delta^{15} \mathrm{~N}_{\mathrm{N} 2 \text {-rock }}$ values of $-0.3 \%$ for the $2.1 \mathrm{kmbs}$ site, $-1.1 \%$ for the $2.4 \mathrm{kmbs}$ site, and $-3.1 \%$ for the $2.9 \mathrm{kmbs}$ site at $\mathrm{KC},+2.5 \%$ at $\mathrm{NR},+4.0 \%$ at $\mathrm{FR},+0.3 \%$ at $\mathrm{TH}$ and $-0.4 \%$ at $\mathrm{BT}$. All these values are higher than the expected values for $\mathrm{N}_{2}$ devolatilization at their peak metamorphic conditions (Fig. 4A-C). Any $\mathrm{N}_{2}$ generated from retrograde metamorphism would make the isotope discrepancy ever larger. At CCS, although all the samples in this study have been severely 
contaminated by air during sampling, their values are still higher than the predicted values (Fig. 4B), not even mention the extremely high $\delta^{15} \mathrm{~N}$ values (up to $17.5 \%$ ) observed on less aircontaminated samples (Montgomery, 1994). These results indicate, while the magnitude and direction of isotope fractionation are indeed consistent with $\mathrm{N}_{2}$ production via devolatilization of ammonium in host rocks, the extents of observed isotopic discrepancy between $\mathrm{N}_{2}$ and host rocks require an additional process to explain the ${ }^{15} \mathrm{~N}$ enrichments in $\mathrm{N}_{2}$.

Diffusive loss of $\mathrm{N}_{2}$ and abiotic $\mathrm{N}_{2}$ reduction are two known processes that can induce ${ }^{15} \mathrm{~N}$ enrichments in remaining $\mathrm{N}_{2}$. Extensive studies of the noble gas concentrations (in the $\mathrm{KC}$ system in particular) have demonstrated that diffusion cannot be a major factor due to the concordance in the ages of the fluids derived from both light (helium and neon) and heavy (argon and xenon) noble gases. In systems where diffusion is a significant process, preferential loss of light noble gases would produce an artifact of significantly younger apparent ages for helium and neon - which is notably not observed in any of the KC studies (Holland et al., 2013; Warr et al., 2018). Accordingly, diffusion process is less likely to significantly impact the $\delta^{15} \mathrm{~N}_{\mathrm{N} 2}$. Rather than diffusion, abiotic $\mathrm{N}_{2}$ reduction may play an important role. Following the cooling of the fluids, $\mathrm{N}_{2}$ input from metamorphic devolatilization diminished to negligible level. Meanwhile, the nonstop interaction between water and $\mathrm{Fe}^{2+}$-bearing minerals (e.g., olivine, pyroxene, biotite, pyrite) in host rocks can produce secondary minerals to seal the fracture system and subsequently establish and maintain a highly reducing environment enriched in $\mathrm{H}_{2}$ and dissolved $\mathrm{Fe}^{2+}$ ( $\mathrm{Li}$ et al., 2016) inside the fracture system. These reducing agents in the fuids, as well as abundant $\mathrm{Fe}^{2+}$-bearing minerals in host rocks, would facilitate abiotic reduction reactions. This is supported by the observation that abiogenic products (e.g., alkanes, acetate, and formate) dominate the gaseous and/or dissolved organic compounds in the $\mathrm{KC}$ fracture fluids (Sherwood 
Lollar et al., 2021) and also widely occur (if not dominate) in other sites in the Canadian Shield (Sherwood Lollar et al., 2006).

Abiotic $\mathrm{N}_{2}$ reduction in a geological setting generally refers to the mineral catalyzed reduction of $\mathrm{N}_{2}$ to produced $\mathrm{NH}_{3}$ or $\mathrm{NH}_{4}{ }^{+}$in fluids, via reactions such as equation (1):

$$
\mathrm{N}_{2}+6 \mathrm{Fe}^{2+}+8 \mathrm{H}^{+} \rightarrow 2 \mathrm{NH}_{4}^{+}+6 \mathrm{Fe}^{3+}
$$

Laboratory experiments demonstrate that abiotic $\mathrm{N}_{2}$ reduction is most efficient at $500{ }^{\circ} \mathrm{C}$ (Brandes et al., 1998), but can also occur at temperatures as low as $22^{\circ} \mathrm{C}$ (Smirnov et al., 2008). Abiotic $\mathrm{N}_{2}$ reduction generally produces a kinetic nitrogen isotopic effect due to the difficulty in breaking the strong $\mathrm{N} \equiv \mathrm{N}$ bond of $\mathrm{N}_{2}$. Based on the nitrogen isotopic measurements of altered igneous rocks, Li et al. $(2007,2014)$ yielded nitrogen isotopic enrichment factors of $-15 \%$ o to $11 \%$ for abiotic $\mathrm{N}_{2}$ reduction at medium- to high-temperature hydrothermal conditions $(>300$ ${ }^{\circ} \mathrm{C}$ ). The magnitude of kinetic nitrogen isotopic effect could be larger at lower temperatures (Li et al., 2009), but no data are available yet. Using the average value of -13\% (Li et al., 2007, 2014) as the lower limit and a Rayleigh fractionation model (Fig. 4D-F), a ballpark estimate can be made for the fractions of $\mathrm{N}_{2}$ required to be reduced in order to match the observed $\delta^{15} \mathrm{~N}$ value in the studied samples. The results suggest that the fractions of the initial $\mathrm{N}_{2}$ that has been abiotically reduced is $25-63 \%$ at $2.1 \mathrm{kmbs}, 21-61 \%$ at $2.4 \mathrm{kmbs}$, and $7-54 \%$ at $2.9 \mathrm{kmbs}$, respectively (Fig. 4D). This decreasing trend along depth is self-consistent with the temperature and time framework that $2.1 \mathrm{kmbs}$ has the shortest time for $\mathrm{N}_{2}$ production but longest time and lowest temperature for abiotic $\mathrm{N}_{2}$ reduction, whereas the $2.9 \mathrm{kmbs}$ has the longest time for $\mathrm{N}_{2}$ production but shortest time and highest temperature for abiotic $\mathrm{N}_{2}$ reduction. Similar extents of abiotic $\mathrm{N}_{2}$ reduction are also obtained from NR $(27-70 \%)$, FR $(35-74 \%)$, TH $(18-65 \%)$, and 
BT (14-63\%) (Fig. 4 E, F). Future examinations on concentrations and isotope compositions of ammonium in the fluids may help to test this possibility.

It is worth noting that, based on mass balance and isotopic comparison, Silver et al. (2012) also proposed that abiotic $\mathrm{N}_{2}$ reduction could have occurred in the subsurface fracture fluids in the Kaapvaal Craton. This implies that abiotic $\mathrm{N}_{2}$ reduction might occur widely in Precambrian cratons.

\subsubsection{The role of radiolysis?}

Another process that is worth briefly discussing is radiolysis. Energy released from the decay of radioactive isotopes of $\mathrm{K}, \mathrm{U}$, Th in host rocks has been shown to play an important role in the long-term production of deep subsurface hydrogen (e.g., Lin et al., 2005; Sherwood Lollar et al., 2014), carbon (Sherwood Lollar et al., 2021), and sulfur (Lin et al., 2006; Li et al., 2016) in deep fracture fluids in the Precambrian cratons around the world. An intriguing question is how much this process may contribute to the nitrogen cycle in these deep saline fracture fluids.

Silver et al. (2012) carried out laboratory experiments to irradiate $\mathrm{NH}_{3} / \mathrm{NH}_{4}{ }^{+}$in anaerobic solutions and observed production of nitrite and nitrate. Consequently, radiolysis has been proposed to be part of the multiple abiotic and biotic mechanisms to drive the nitrogen cycle in the subsurface fluids in the Kaapvaal Craton (Silver et al., 2012). Radiolytic impact on fixed ammonium in minerals and rocks is poorly examined by far. It is unclear whether radiolysis in the Precambrian cratonic environments facilitate $\mathrm{N}_{2}$ production. But laboratory experiments on the $\mathrm{N}_{2}-\mathrm{H}_{2}-\mathrm{H}_{2} \mathrm{O}$ system (e.g., Etoh et al., 1987; Karasawa et al., 1991) have demonstrated that $\mathrm{N}_{2}$ can be consumed by radiolysis to form not only $\mathrm{NH}_{4}{ }^{+}$as the dominant product (Karasawa et al., 1991) but also $\mathrm{NO}_{3}^{-}$(Etoh et al., 1987), via overall reactions described in equations (2)-(3). 


$$
\left\{\begin{array}{c}
\mathrm{N}^{\cdot}+3 \mathrm{H}^{\cdot}+\mathrm{H}^{+} \rightarrow \mathrm{NH}_{4}^{+} \\
2 \mathrm{~N}^{\cdot}+5 \mathrm{O}^{\cdot}+2 \mathrm{OH}^{-} \rightarrow 2 \mathrm{NO}_{3}^{-}+\mathrm{H}_{2} \mathrm{O}
\end{array}\right.
$$

This differs from the mineral catalyzed abiotic $\mathrm{N}_{2}$ reduction process in equation (1). However, the nitrogen isotope fractionation during radiolytic decomposition of $\mathrm{N}_{2}$ has not been constrained, although a kinetic isotopic effect likely occurs. Future studies integrating laboratory examination of nitrogen isotope fractionations during radiolysis of the $\mathrm{N}_{2}-\mathrm{H}_{2}-\mathrm{H}_{2} \mathrm{O}$ system and the analyses of concentrations and isotope compositions of ammonium and nitrate (if there is any) in fracture fluids are necessary to further assess these processes in the deep subsurface of Precambrian cratons.

\subsubsection{Microbial nitrogen recycling?}

The samples studied here contain a set of $\mathrm{N}_{2}$ samples from one of the long-term monitoring boreholes (BH12299 at $2.4 \mathrm{kmbs)}$ at the KC Observatory collected over nearly 10 years since the completion of the borehole drilling in May 2007. Interestingly, the $\delta^{15} \mathrm{~N}_{\mathrm{N} 2}$ values of this set of samples (Table 1) display a trend of steady decrease (for $>1 \%$ ) over time (Fig. 5). Since significant addition of an air component over time can be ruled out based on the ${ }^{15} \mathrm{~N}^{15} \mathrm{~N}$ results (Labidi et al., 2020), this trend suggests that another in-situ source of ${ }^{15} \mathrm{~N}$-depleted $\mathrm{N}_{2}$ has been progressively added into the original $\mathrm{N}_{2}$ reservoir in this borehole over the monitoring period. Although the $\mathrm{N}_{2}$ in the deeper fracture fluids (e.g., $2.9 \mathrm{kmbs}$ ) at the KC Observatory is relatively ${ }^{15} \mathrm{~N}$ depleted, it cannot be the source for the $2.4 \mathrm{kmbs}$ fracture fluids because current evidence supports hydrogeologic isolation between these fracture systems (Warr et al., 2018, 2021b). One potential in-situ source for a ${ }^{15} \mathrm{~N}$-depleted $\mathrm{N}_{2}$ source in the $2.4 \mathrm{kmbs}$ fracture system 
is dissolved ammonium. The temperature and $\mathrm{pH}$ conditions of the $\mathrm{KC}$ fluids favor the preservation of ammonium as the net product from abiotic $\mathrm{N}_{2}$ reduction (Li et al., 2012). This may therefore provide an ideal ${ }^{15} \mathrm{~N}$-depleted source for this secondary $\mathrm{N}_{2}$.

The abiotic conversion of $\mathrm{NH}_{4}{ }^{+} / \mathrm{NH}_{3}$ to $\mathrm{N}_{2}$ requires either oxic condition and/or relatively high temperature $\left(>500^{\circ} \mathrm{C}\right)$ without catalyst (Li et a., 2009). Even with efficient catalyst (e.g., $\mathrm{Fe}$ ), the conversion rate is very slow at temperatures $<300^{\circ} \mathrm{C}$ ( $\mathrm{Li}$ et al., 2021d). In addition, no evidence to show an oxic environment in the studied fracture systems. Thus, abiotic conversion of $\mathrm{NH}_{4}{ }^{+} / \mathrm{NH}_{3}$ at the low-temperature environment $\left(24{ }^{\circ} \mathrm{C}\right.$ at $\left.2.4 \mathrm{kmbs}\right)$ may not contribute detectable $\mathrm{N}_{2}$ to BH12299 fluid at a decadal time scale. Microbially-driven anaerobic oxidation of ammonium (e.g., Van De Graaf et al., 1995; Byrne et al., 2008) is a more efficient mechanism to convert ammonium to $\mathrm{N}_{2}$. Microbial recycling of nitrogen has been suggested to occur in subsurface fracture fluids in the Kaapvaal Craton (Silver et al., 2012; Lau et al 2016) and elsewhere in the Canadian Shield (Sheik et al., 2021), but cannot be explored further for the KC samples due to the lack of biogeochemical data and isotopic compositions of other nitrogen species (ammonium, nitrite or nitrate, if there is any) in these fracture fluids. It is worth highlighting though that recent studies using cell counts and culture-based methods have identified low abundance of $\mathrm{H}_{2}$-utilizing, alkane-oxidizing sulfate-reducing bacteria in the $\mathrm{KC}$ fracture fluids (Lollar et al., 2019; Wilpiszeski et al., 2020). This directly supports the prevailing hypothesis that microbial activities could have been sustained over geological timescale in the long isolated KC fracture fluids based on sulfur isotopic studies (Li et al., 2016). Microbial activities related to methanogenesis and methanotrophy in the $2.4 \mathrm{kmbs} \mathrm{KC}$ fracture fluids have been further inferred from the isotopic signatures of $\mathrm{CH}_{4}$ (Sherwood Lollar et al., 2002; Young et al., 2017, Warr et al., 2021b). In particular, a potential ongoing addition of biogenic $\mathrm{CH}_{4}$ to the 
same fracture fluid system (BH12299) has been suggested based on a temporal decrease in the mass-18 isotopologues of $\mathrm{CH}_{4}$ over the last decade (Warr et al., 2021b). A speculation is that the $\mathrm{KC}$ fracture fluids could have been or is being influenced by microbial activities involving multiple metabolic pathways including $\mathrm{H}_{2}$ oxidation, sulfate reduction, methanogenesis, anaerobic oxidation of methane, and anaerobic oxidation of ammonium. This hypothesis will need to be tested by future microbial studies with detailed constraints on metabolic pathways and their geochemical fingerprints.

\section{Conclusions}

$\mathrm{N}_{2}$ in the highly reducing saline fracture waters of the Canadian Shield provides a novel opportunity to look into the (bio)geochemical nitrogen recycling processes in deep subsurface systems that have been long investigated in the context of the deep carbon cycle and subsurface life, but to date with very little characterization and quantification of the deep nitrogen cycle. Here we observed that the $\mathrm{N}_{2}$ in subsurface fracture waters with residence times from hundreds of million years to billions of years in the Canadian Shield were more enriched in ${ }^{15} \mathrm{~N}$ than the $\mathrm{N}_{2}$ samples from fracture waters with residence times of hundreds of thousands to tens of millions of years in the Fennoscandian Shield and the Kaapvaal Craton. Detailed isotopic comparison between the Canadian Shield $\mathrm{N}_{2}$ samples and their potential sources excludes air, dissolved inorganic nitrogen, and organic compounds in host rocks as their sources. Instead, fixed ammonium in igneous host rocks is the most likely source. Modeling of nitrogen devolatilization of igneous rocks supports this interpretation, but also suggests that a second process is required to account for the observed ${ }^{15} \mathrm{~N}$ enrichments in the $\mathrm{N}_{2}$ samples from the Canadian Shield. Longterm abiotic $\mathrm{N}_{2}$ reduction in the closed fracture water systems is the most likely process. The 
data in this study imply a common occurrence of abiotic $\mathrm{N}_{2}$ reduction in the long isolated, highly reducing fracture water systems in the Canadian Shield, and possibly in similar environments on the early Earth and other planets. The accumulation of the ammonium product can not only provide a critical reagent for abiotic synthesis of amino acid (an essential building block for life) toward the origin of life but also supply a necessary nutrient to support potential ammonium assimilating or anaerobic ammonium oxidizing microbes in these environments.

\section{Acknowledgements}

This study was partially supported by NSERC and Canada Research Chair funding to BSL and NSERC Discovery grant to LL. BSL is a Fellow and Co-Director for the CIFAR Earth 4D program in subsurface science and exploration. We thank Thomas Eckert and Scott Mundle for field assistance and Georges Lacrampe-Couloume for lab assistance. Thanks are due to colleagues and supporters at the mines whose efforts and support for the sampling program were invaluable. This manuscript benefited from constructive comments by Dr. Eva Stüeken and an anonymous reviewer.

\section{References}

Abramov, O., Kring, D.A., 2004. Numerical modeling of an impact-induced hydrothermal system at the Sudbury crater. J. Geophys. Res., 109: E10007. Doi:10.1029/2003JE002213.

Barrie, C.T., Davis, D.W., 1990. Timing of magmatism and deformation in the Kamiskotia-Kidd Creek area, western Abitibi Subprovince, Canada. Precam. Res., 46: 217-240.

Bebout, G.E., Fogel, M.L., 1992. Nitrogen-isotope compositions of metasedimentary rocks in the Catalina Schist, California: implications for metamorphic devolatilization history. Geochim. Cosmochim. Acta, 56: 2839-2849. 
Bleeker, W., Parrish, R.R., 1996. Stratigraphy and U-Pb zircon geochronology of Kidd Creek: implications for the formation of giant volcanogenic massive sulphide deposits and the tectonic history of the Abitibi greenstone belt. Can. J. Earth Sci., 33: 1213-1231.

Brandes, J.A., Boctor, N.Z., Cody, G.D., Cooper, B.A., Hazen, R.M., Yoder Jr, H.S., 1998. Abiotic nitrogen reduction on the early Earth. Nature, 395: 365-367.

Busigny, V., Cartigny, P., Philippot, P., Ader, M., Javoy, M., 2003. Massive recycling of nitrogen and other fluid-mobile elements $(\mathrm{K}, \mathrm{Rb}, \mathrm{Cs}, \mathrm{H})$ in a cold slab environment: evidence from HP to UHP oceanic metasediments of the Schistes Lustrés nappe (western Alps, Europe). Earth and Planetary Science Letters, 215: 27-42.

Busigny, V., Laverne, C., Bonifacie, M., 2005. Nitrogen content and isotopic composition of oceanic crust at a superfast spreading ridge: a profile in altered basalts from ODP Site 1256, Leg 206. Geochem. Geophys. Geosyst., 6: Q12O01.

Byre, N., Strous, M., Crépeau, V., Kartal, B., Birrien, J.-L., Schmid, M., Lesongeur, F., Schouten, S., Jaeschke, A., Jetten, M., Prieur, D., Godfroy, A., 2008. Presence and activity of anaerobic ammonium-oxidizing bacteria at deep-sea hydrothermal vents. The ISME J., 3: 117-123.

Chen, Y., Fleet, M.E., Pan, Y., 1993. Platinum-group minerals and gold in arsenic-rich ore at the Thompson Mine, Thompson Nickel Belt, Manitoba, Canada. Mineral. Petrol., 49: 127146.

Couëslan, C.G., Pattison, D.R.M., Dufrane, S.A., 2013. Paleoproterozoic metamorphic and deformation history of theThompson Nickel Belt, Superior Boundary Zone, Canada, from in situ U-Pb analysis of monazite. Precam. Res., 237: 13-35.

Davis, D.W., 2008. Sub-million-year age resolution of Precambrian igneous events by thermal extraction-thermal ionization mass spectrometer $\mathrm{Pb}$ dating of zircon: Application to crystallization of the Sudbury impact melt sheet. Geology, 36: 383-386.

Davis, D.W., Schandl, E.S., Wasteneys, H.A., 1994. U-Pb dating of minerals in alteration halos of Superior Province massive sulfide deposits: syngenesis versus metamorphism. Contrib. Mineral. Petrol., 115: 427-437.

Deng, Y., Li, Y., Li, L., 2018. Experimental investigation of nitrogen isotopic effects associated with ammonia degassing at $0-70^{\circ} \mathrm{C}$. Geochim. Cosmochim. Acta, 226: 182-191.

Dimroth, E., Imreh, L., Goulet, N., Rocheleau, M., 1983. Evolution of the south-central part of the Archean Abitibi belt, Quebec. Part II: Tectonic evolution and geomechanical model. Can. J. Earth Sci., 20: 1355-1373.

Doig, F., Sherwood Lollar, B., Ferris, F.G., 1995. Evidence for abundant microbial communities in Canadian Shield groundwaters - an in situ biofilm experiment. Geomicrob. J., 13: 91101.

Eigenbrode, J.L., Freeman, K.H., 2006. Late Archean rise of aerobic microbial ecosystems. PNAS 103, 15759-15764.

Etoh, Y., Karasawa, H., Ibe, E., Sakagami, M., Yasuda, T., 1987. Radiolysis of $\mathrm{N}_{2}-\mathrm{H}_{2} \mathrm{O}$ systems. J. Nuclear Sci. Techol., 24: 672-674.

Faggart, B.E., Basu, A.R., Tatsumoto, M., 1985. Origin of the Sudbury complex by meteoritic impact: neodymium isotopic evidence. Science, 230: 436-439.

Fleet, M.E., Barnett, R.L., Morris, W.A., 1987. Prograde metamorphism of the Sudbury igneous complex. Can. Mineral., 25: 499-514.

Frape, S.K., Fritz, P., McNutt, R.H., 1984. Water-rock interaction and chemistry of groundwaters from the Canadian Shield. Geochim. Cosmochim. Acta, 48: 1617-1627. 
Freed, R.L., Peacor, D.R., 1989. Variability in temperature of the smectite/illite reaction in Gulf Coast sediments. Clay Minerals, 24: 171-180.

Goodwin, A., 1996. Principles of Precambrian Geology. Academic Press, pp 327.

Haendel, D., Mühle, K., Nitzsche, H.-M., Stiehl, G., Wand, U., 1986. Isotopic variations of the fixed nitrogen in metamorphic rocks. Geochim. Cosmochim. Acta, 50: 749-758.

Hannington, M.D., Bleeker, W., Kjarsgaard, I., 1999. Sulfide mineralogy, geochemistry, and ore genesis of the Kidd Creek deposit: Part I. North, Central and South orebodies. In: Hannington, M.D., Barrie, C.T. (Eds.), The Giant Kidd Creek Volcanogenic Massive Sulfide Deposit, Western Abitibi Subprovince, Canada, pp. 163-224.

Heard, A.W., Warr, O., Borgonie, G., Linage, B., Kuloyo, O., Fellowes, J.W., Magnabosco, C., Lau, M.C.Y., Erasmus, M., Cason, E.D., van Heerden, E., Kieft, T.L., Mabry, J.C., Onstott, T.C., Sherwood Lollar, B., Ballentine, C.J., 2018. South African crustal fracture fluids preserve paleometeoric water signatures for up to tens of millions of years. Chem. Geol., 493: 379-395.

Hoffmann, P.F., 1989. Precambrian geology and tectonic history of North America. In: Bally, A.W., Palmer, A.R. (Eds.), The Geology of North America - An Overview. The Geological Society of America, pp. 447-512.

Holland, G., Sherwood Lollar, B., Li, L., Lacrampe-Couloume, G., Slater, G., Ballentine, C.J., 2013. Deep fracture fluids isolated in the crust since the Precambrian era. Nature, 497: 357-360.

Hulbert, L., Hamilton, M.A., Horan, M.F., Scoates, R.F.J., 2005. U-Pb zircon and Re-Os Isotope geochronology of mineralized ultramafic intrusions and associated nickel ores from the Thompson nickel belt, Manitoba, Canada. Econ. Geol., 100: 29-41.

Itävaara, M., Nyyssönen, M., Kapanen, A., Ahonen, L., Kukkonen, I.T., 2011. Characterization of bacterial diversity to a depth of $1500 \mathrm{~m}$ in the Outokumpu deep borehole, Fennoscandian Shield. FEMS Microbiol. Ecol., 77: 295-309.

Karasawa, H., Ibe, E., Uchida, S., Etoh, Y., Yasuda, T., 1991. Radiation induced decomposition of ntirogen. Int. d. Radiat. Appl. Instrum. Part C Radiat. Phys. Chem., 37: 193-197.

Kietäväinen, R., Ahonen, L., Kukkonen, I.T., Niedermann, S., Wiersberg, T., 2014. Noble gas residence times of saline waters within crystalline bedrock, Outokumpu Deep Drill Hole, Finland. Geochim. Cosmochim. Acta, 145: 159-174.

Kipfer, R., Aeschbach-Hertig, W., Peeters, F. and Stute, M., 2002. Noble gases in lakes and ground waters. In: Noble Gases in Geochemistry and Cosmochemistry (eds., D. Porcelli, C.J. Ballentine and R. Wieler). Reviews in Mineralogy and Geo-chemistry. Mineralogical Society of America, pp. 615-700.

Krogh, T.E., McNutt, R.H., Davis, G.L., 1982. Two high precision U-Pb zircon ages for the Sudbury nickel irruptive. Can. J. Earth Sci., 19: 723-728.

Labidi, J., Barry, P.H., Bekaert, D.V., Broadley, M.W., B., M., Giunta, T., Warr, O., Sherwood Lollar, B., Fischer, T.P., Avice, G., Caracausi, A., Ballentine, C.J., Halldórsson, S.A., Stefánsson, A., Kurz, M.D., Kohl, I.E., Young, E.D., 2020. Hydrothermal 15N15N abundances constrain the origins of mantle nitrogen. Nature, 580: 367-374.

Lau, M.C.Y., Kieft, T.L., Kuloyo, O., Linage-Alvarez, B., van Heerden, E., Lindsay, M.R., Magnabosco, C., Wang, W., Wiggins, J.B., Guo, L., Perl,am, D.H., Kyin, S., Shwe, H.H., Harris, R.L., Oh, Y., Yi, M.J., Purtschert, R., Slater, G.F., Ono, S., Wei, S., Li, L., Sherwood Lollar, B., Onstott, T.C., 2016. An oligotrophic deep-subsurface community 
dependent on syntrophy is dominated by sulfur-driven autotrophic denitrifiers. PNAS, 113: E7927-E7936.

Li, L. and Bebout, G.E., 2005. Carbon and nitrogen geochemistry of sediments in the Central American convergent margin: Insights regarding subduction input fluxes, diagenesis, and paleoproductivity. J. Geophys. Res., 110: B11202, doi:10.1029/2004JB003276.

Li, L., Bebout, G.E., Idleman, B.D., 2007. Nitrogen concentration and $\delta^{15} \mathrm{~N}$ of altered oceanic crust obtained on ODP Legs 129 and 185: insights into alteration-related nitrogen enrichment and the nitrogen subduction budget. Geochim. Cosmochim. Acta, 71: 23442360 .

Li, L., Cartigny, P., Ader, M., 2009. Kinetic nitrogen isotope fractionation associated with thermal decomposition of $\mathrm{NH}_{3}$ : Experimental results and potential applications to trace the origin of $\mathrm{N}_{2}$ in natural gas and hydrothermal systems. Geochim. Cosmochim. Acta, 73: 6282-6297.

Li, L., Sherwood Lollar, B., Li, H., Wortmann, U.G., Lacrampe-Couloume, G., 2012. Ammonium stability and nitrogen isotope fractionations for $\mathrm{NH}_{4}{ }^{+}-\mathrm{NH}_{3(\mathrm{aq})}-\mathrm{NH}_{3}(\mathrm{gas})$ systems at $20-70{ }^{\circ} \mathrm{C}$ and $\mathrm{pH}$ of 2-13: Applications to habitability and nitrogen cycling in low-temperature hydrothermal systems. Geochim. Cosmochim. Acta, 84: 280-296.

Li, L., Zheng, Y.-F., Cartigny, P., Li, J., 2014. Anomalous nitrogen isotopes in ultrahighpressure metamorphic rocks from the Sulu orogenic belt: Effect of abiotic nitrogen reduction during fluid-rock interaction. Earth Planet. Sci. Lett., 403: 67-78.

Li, L., Wing, B.A., Bui, T.H., McDermott, J.M., Slater, G.F., Wei, S., Lacrampe-Couloume, G., Sherwood Lollar, B., 2016. Sulfur mass-independent fractionation in subsurface fracture waters indicates a long-standing sulfur cycle in Precambrian rocks. Nature Communications, 7: 1325. Doi: 10.1038/ncomms 13252.

Li, L., Li, K., Li, Y., Zhang, J., Du, Y., Labbe, M., 2021a. Recommendations for combustionbased nitrogen isotope analysis for silicate minerals and rocks. Rapid Comm. Mass Spectrometry, 35: e9075. Doi: 10.1002/rcm.9075.

Li, L., He, Y., Zhang, Z., Liu, Y., 2021b. Nitrogen isotope fractionations among gaseous and aqueous $\mathrm{NH}_{4}{ }^{+}, \mathrm{NH}_{3}, \mathrm{~N}_{2}$ and metal-ammine complexes: Theoretical calculations and applications. Geochim. Cosmochim. Acta, 295: 80-97.

Li, Y., Li, L., Wu, Z., 2021c. First-principles calculations of equilibrium nitrogen isotope fractionations among aqueous ammonium, silicate minerals and salts. Geochim. Cosmochim. Acta, 297: 220-232.

Li, L., Cartigny, P., Li, K., 2021d. Experimental investigation of formation and decomposition of roaldite in ammonia atmosphere at $300-700^{\circ} \mathrm{C}$ and associated nitrogen isotope fractionations. Geochim. Cosmochim. Acta, 300: 65-78.

Lightfoot, P.C., Farrow, C.E.G., 2002. Geology, geochemistry, and mineralogy of the Worthington Offset Dike: A genetic model for offset dike mineralization in the Sudbury igneous complex. Econ. Geol., 97: 1419-1446.

Lin, L.-H., Hall, J.A., Lippmann, J., Ward, J., Sherwood Lollar, B., DeFlaun, M., Rothmel, R., Moser, D.P., Gihring, T.M., Mislowack, B., Onstott, T.C., 2005. Radiolytic $\mathrm{H}_{2}$ in continental crust: Nuclear power for deep subsurface microbial communities. Geochem. Geophys. Geosyst., 6: Q07003.

Lin, L.-H., Wang, P.-L., Lippmann-Pipke, J., Boice, E., Pratt, L.M., Sherwood Lollar, B., Brodie, E.L., Hazen, T.C., Andersen, G.L., DeSantis, T.Z., Moser, D., Kershaw, D., 
Onstott, T.C., 2006. Long-term sustainability of a high-energy, low-diversity crustal biome. Science, 314: 479-482.

Lippmann-Pipke, J., Sherwood Lollar, B., Niedermann, S., Stroncik, N.A., Naumann, R., van Heerden, E., Onstott, T.C., 2011. Neon identifies two billion year old fluid component in Kaapvaal Craton. Chem. Geol., 283: 287-296.

Lippmann, J., Stute, M., Torgersen, T., Moser, D.P., Hall, J.A., Lin, L.-H., Borcsik, M., Bellamy, R.E.S., Onstott, T.C., 2003. Dating ultra-deep mine waters with noble gases and ${ }^{36} \mathrm{Cl}$, Witwatersrand Basin, South Africa. Geochim. Cosmochim. Acta, 67: 4597-4619.

Lollar, G.S., Warr, O., Telling, J., Osburn, M.R., Sherwood Lollar, B., 2019. 'Follow the Water': Hydrogeochemical constraints on microbial investigations $2.4 \mathrm{~km}$ below surface at the Kidd Creek Deep Fluid and Deep Life Observatory. Geomicrobiol. J., 36: 859-872.

Magnabosco, C., Ryan, K., Lau, C.Y.M., Kuloyo, O., Sherwood Lollar, B., Kieft, T., van Heerden, E., onstott, T.C., 2015. A metagenomic window into carbon metabolism at 3 $\mathrm{km}$ depth in Precambrian Continental Crust. The ISME Journal, 10: 730-741.

Magnabosco, C., Timmers, P.H.A., Lau, M.C.Y., Borgonie, G., Linage-Alvarez, B., Kuloyo, O., Alleva, R., Kieft, T.L., Slater, G.S., van Heerden, E., Sherwood Lollar, B., Onstott, T.C., 2018. Fluctuations in populations of subsurface methane oxidizers in coordination with changes in electron acceptor availability. FEMS Microb. Ecol., 94: doi: 10.1093/femsec/fiy089.

Meldrum, A., AbdelRahman, A.F.M., Martin, R.F., Wodicka, N., 1997. The nature, age and petrogenesis of the Cartier batholith, northern flank of the Sudbury structure, Ontario, Canada. Precam. Res., 82: 265-285.

Mercier-Langevin, P., Dubé, B., Hannington, M.D., davis, D.W., Lafrance, B., Goseelin, G., 2007. The LaRonde Penna Au-rich volcanogenic massive sulfide deposit, Abitibi greenstone belt, Quebec: Part I. geology and geochronology. Econ. Geol., 102: 585-609.

Montgomery, J., 1994. An isotopic study of $\mathrm{CH}_{4}$ and associated $\mathrm{N}_{2}$ and $\mathrm{H}_{2}$ gases in Canadian Shield mining environments. MSc Thesis. University of Toronto.

NASEM (National Academies of Sciences, Engineering, and Medicine), 2019. An Astrobiology Strategy for the Search for Life in the Universe. The National Academies Press, Washington, D.C. https://doi.org/10.17226/25252.

Onstott, T.C., Lin, L.-H., Davidson, M., Mislowack, B., Borcsik, M., Hall, J., Slater, G.F., Ward, J.A., Sherwood Lollar, B., Lippmann-Pipke, J., Boice, E., Pratt, L.M., Pfiffner, S., Moser, D.P., Gihring, T.M., Kieft, T.L., Phelps, T.J., van Heerden, E., Litthaur, D., DeFlaun, M., Rothmel, R., Wanger, G., Southam, G., 2006. The origin and age of biogeochemical trends in deep fracture water of the Witwatersrand Basin, South Africa. Geomicrobiol. J., 23: 369-414.

Paktunç, A., 1984. Metamorphism of the ultramafic rocks of the Thompson mine, Thompson Nickel Belt, northern Manitoba. Can. Mineral., 22: 77-91.

Powell, W.G., Carmichael, D.G., Hodgson, C.J., 2011. Conditions and timing of metamorphism in the southern Abitibi Greenstone Belt, Quebec. Can. J. Earth Sci., 32: 787-805.

Prior, G.J., Gibson, H.L., Watkinson, D.H., Cook, R.E., 1999. Anatomy, lithogeochemistry, and emplacement mechanisms for the QP rhyolite, Kidd Creek mine, Timmins, Ontario. In: Hannington, M.D., Barrie, C.T. (Eds.), Economic Geology Monograph 10: The Giant Kidd Creek Volcanogenic Massive Sulfide Deposit, Western Abitibi Subprovince, Canada. the Economic Geology Publishing Co., pp. 123-142. 
Sadofsky, S. J. and Bebout, G.E., 2004. Nitrogen geochemistry of subducting sediments: New results from the Izu-Bonin-Mariana margin and insights regarding global nitrogen subduction. Geochem. Geophys. Geosyst., 5: Q03I15, doi:10.1029/2003GC000543.

Sherwood Lollar, B., Frape, S.K., Fritz, P., Macko, S.A., Welhan, J.A., Blomqvist, R., Lahermo, P.W., 1993a. Evidence for bacterially generated hydrocarbon gas in Canadian Shield and Fennoscandian Shield rocks. Geochim. Cosmochim. Acta, 57: 5073-5085.

Sherwood Lollar, B., Frape, S.K., Weise, S.M., Fritz, P., Macko, S.A., Welhan, J.A., 1993b. Abiogenic methanogenesis in crystalline rocks. Geochim. Cosmochim. Acta, 57: 50875097.

Sherwood Lollar, B., Heuer, V., McDermott, J.M., Tille, S., Warr, O., Moran, J.J., Telling, J., Hinrichs, K.-U., 2021. A window into the abiotic carbon cycle - Acetate and formate in fracture waters in 2.7 billion year-old host rocks of the Canadian Shield. Geochim. Cosmochim. Acta, 294: 295-314.

Sherwood Lollar, B., Westgate, T., Ward, J., Slater, G.F., Lacrampe-Couloume, G., 2002. Abiogenic formation of alkanes in the Earth's crust as a minor source for global hydrocarbon reservoirs. Nature, 416: 522-524.

Sherwood Lollar, B., Lacrampe-Couloume, G., Slater, G.F., Ward, J., Moser, D.P., Gihring, T.M., Lin, L.-H., Onstott, T.C., 2006. Unravelling abiogenic and biogenic sources of methane in the Earth's deep subsurface. Chem. Geol., 226: 328-339.

Sherwood Lollar, B., Lacrampe-Couloume, G., Voglesonger, K., Onstott, T.C., Pratt, L.M., Slater, G.F., 2008. Isotopic signatures of $\mathrm{CH}_{4}$ and higher hydrocarbon gases from Precambrian Shield sites: a model for abiogenic polymerization of hydrocarbons. Geochim. Cosmochim. Acta, 72: 4778-4795.

Sherwood Lollar, B., Onstott, T.C., Lacrampe-Couloume, G., Ballentine, C.J., 2014. The contribution of the Precambrian continental lithosphere to global $\mathrm{H}_{2}$ production. Nature, 516: 379-382.

Sherwood Lollar, B., Voglesonger, K., Lin, L.-H., Lacrampe-Couloume, G., Telling, J., Abrajano, T.A., Onstott, T.C., Pratt, L.M., 2007. Hydrogeologic controls on episodic $\mathrm{H}_{2}$ release from Precambrian fractured rocks - Energy for deep subsurface life on Earth and Mars. Astrobiology, 7: 971-986.

Sheik, C.S., Badalamenti, J.P., Telling, J., Hsu, D., Alexander, S.C., Bond, D.R., Gralnick, J.A., Sherwood Lollar, B., Toner, B.M., 2021. Novel microbial groups drive productivity in an Archean iron formation. Front. Microbiol., 12: doi: 10.3389/fmicb.2021.627595.

Silver, B.J., Raymond, R., Sigman, D.M., Prokopeko, M., Sherwood Lollar, B., LacrapeCoulome, Fogel, M.L., Pratt, L.M., Lefticariu, L., Onstott, T.C., 2012. The origin of $\mathrm{NO}_{3}{ }^{-}$ and $\mathrm{N}_{2}$ in deep subsurface fracture water of South Africa. Chem. Geol., 294-295: 51-62.

Slack, P.B., 1974. Variance of terrestrial heat flow between the North American Craton and the Canadian Shield. Geol. Soc. Amer. Bullet., 85: 519-522.

Smirnov, A., Hausner, D., Laffers, R., Strongin, D.R., Schoonen, M., 2008. Abiotic ammonium formation in the presence of Ni-Fe metals and alloys and its implications for the Hadean nitrogen cycle. Geochem. Trans., 9: 5. Doi: 10.1186/1467-4866-9-5.

Smith, P.E., Schandl, E.S., York, D., 1993. Timing of metasomatic alteration of the Archean Kidd Creek massive sulfide deposit, Ontario, using ${ }^{40} \mathrm{Ar}-{ }^{39} \mathrm{Ar}$ laser dating of single crystals of fuchsite. Econ. Geol., 88: 1636-1642. 
Telling, J., Voglesonger, K., Sutcliffe, C.N., Lacrampe-Couloume, G., Edwards, E., Sherwood Lollar, B., 2018. Bioenergetic constraints on microbial hydrogen utilization in Precambrian deep crustal fracture fluids. Geomicrobiol. J., 35: 108-119.

Thompson, L.M., Spray, J.G., Kelley, S.P., 1998. Laser probe argon-40/argon-39 dating of pseudotachylyte from the Sudbury Structure: Evidence for postimpact thermal overprinting in the North Range. Meteor. Planet. Sci., 33: 1259-1269.

Ward, J., Slater, G., Moser, D., Lin, L.-H., Lacrampe-Couloume, G., Bonin, A.S., Davidson, M., Hall, J.A., Mislowack, B., Bellamy, R.E.S., Onstott, T.C., Sherwood Lollar, B., 2004. Microbial hydrocarbon gases in the Witwatersrand Basin, South Africa: Implications for the deep biosphere. Geochim. Cosmochim. Acta, 68: 3239-3250.

Warr, O., Sherwood Lollar, B., Fellowes, J., Sutcliffe, C.N., McDermott, J.M., Holland, G., Mabry, J.C., Ballentine, C.J., 2018. Tracing ancient hydrogeological fracture network age and compartmentalisation using noble gases. Geochim. Cosmochim. Acta, 222: 340-362.

Warr, O., Giunta, T., Ballentine, C.J., Sherwood Lollar, B., 2019. Mechanisms and rates of ${ }^{4} \mathrm{He}$, ${ }^{40} \mathrm{Ar}$, and $\mathrm{H}_{2}$ production and accumulation in fracture fluids in Precambrian Shield environments. Chem. Geol., 530: 119322.

Warr, O., Giunta, T., Onstott, T.C., Kieft, T., Harris, R.L., Nisson, D.M., Sherwood Lollar, B., 2021a. The role of low-temperature ${ }^{18} \mathrm{O}$ exchange in the isotopic evolution of deep subsurface fluids. Chem. Geol., 561: 120027.

Warr, O., Young, E.D., Giunta, T., Kohl, I., Ash, J., Sherwood Lollar, B., 2021b. Highresolution, long-term isotopic and isotopologue variation identifies the sources and sinks of methane in a deep subsurface carbon cycle. Geochim. Cosmochim. Acta, 294: 315334.

Wilpiszeski, R.L., Sherwood Lollar, B., Warr, O., House, C.H. (2020) In situ growth of halophilic bacteria in saline fracture fluids from $2.4 \mathrm{~km}$ below surface in the deep Canadian Shield. Life, 10: 307. Doi: 10.3390/life10120307.

Yeung, L.Y., Li, S., Kohl, I.E., Haslun, J.A., Ostrom, N.E., Hu, H., Fischer, T.P., Schauble, E.A., Young, E.D., 2017. Extreme enrichment in atmospheric 15N15N. Science Advances, 3: Article eaao6741.

Young, E.D., Kohl, I.E., Sherwood Lollar, B., Etiope, G., Rumble, D., Li, S., Haghnegahdar, M. A., Schauble, E.A., McCain, K.A., Foustoukos, D.I., Sutcliffe, N.C., Warr, O., Ballentine, C.J., Onstott, T.C., Hosgormez, H., Neubeck, A., Marques, J.M., PerezRodriguez, I., Rowe, A.R., LaRowe, D.E., Magnabosco, C., Bryndzia, T., 2017. The relative abundances of resolved ${ }^{12} \mathrm{CH}_{2} \mathrm{D}_{2}$ and ${ }^{13} \mathrm{CH}_{3} \mathrm{D}$ and mechanisms controlling isotopic bond ordering in abiotic and biotic methane gases. Geochim. Cosmochim. Acta, 203: 235-264.

Zwanzig, H.V., Macek, J.J., McGregor, C.R., 2007. Lithostratigraphy and geochemistry of the high-grade metasedimentary rocks in the Thompson nickel belt and adjacent Kisseynew domain, Manitoba: implications for nickel exploration. Econ. Geol., 102: 1197-1216. 


\section{Figure captions}

Fig. 1. Location map of sample sites for this study together with the sites with $\delta^{15} \mathrm{~N}_{\mathrm{N} 2}$ values reported in Sherwood Lollar et al. (1993a). The general geology of the Canadian Shield is shown in the inserted panel (revised from Hoffmann, 1989; Li et al., 2016; Warr et al., 2019). BT= Birchtree; $\mathrm{TH}=$ Thompson; $\mathrm{KC}=$ Kidd Creek; FR = Fraser; NR = Nickel Rim; CCS = Copper Cliff South; LR = LaRonde; VDO = Val D’Or; NT = Norita

Fig. 2. Comparison of $\delta^{15} \mathrm{~N}$ values of $\mathrm{N}_{2}$ with $\mathrm{N}_{2} / \mathrm{O}_{2}$ ratio (A) and $\mathrm{N}_{2} / \mathrm{Ar}$ ratio $(\mathrm{B}, \mathrm{C})$ for subsurface fracture waters from the Canadian Shield. Error bars are smaller than data symbols. These highly reducing fracture waters produce $\mathrm{H}_{2}$ and do not contain $\mathrm{O}_{2}$, thus the $\mathrm{N}_{2} / \mathrm{O}_{2}$ ratio can be used as a robust index for air contamination. The vertical line $\left(\mathrm{N}_{2} / \mathrm{O}_{2}=15\right)$ in panel A divides significantly contaminated samples to the left and less contaminated samples to the right. In contrast, the fracture waters contain various amounts of ${ }^{40} \mathrm{Ar}$ (and $\mathrm{N}_{2} / \mathrm{Ar}$ ratio) from the decay of ${ }^{40} \mathrm{~K}$ in host rocks. Thus $\mathrm{N}_{2} / \mathrm{Ar}$ ratios cannot be used to quantify the air component. All samples with known $\mathrm{N}_{2} / \operatorname{Ar}$ ratios $\delta^{15} \mathrm{~N}$ values are compiled in Panel $\mathrm{B}$. Whereas only samples with known $\mathrm{N}_{2} / \mathrm{O}_{2}$ values of $>15$ are plotted in panel C. Historical samples marked by "(M)" are unpublished thesis data from Montgomery (1994); samples marked by “(BSL)” are from Sherwood Lollar et al. (1993a). Both are shown as filled grey symbols.

Fig. 3. Comparison of $\delta^{15} \mathrm{~N}$ values of $\mathrm{N}_{2}$ in subsurface fracture waters from the Kaapvaal Craton (A), the Fennoscandian Shield (B), and the Canadian Shield (C). The Canadian Shield samples are consistently more ${ }^{15} \mathrm{~N}$ enriched than those from the other two cratons. See text for discussion.

Fig. 4. Comparison of $\Delta^{15} \mathrm{~N}_{\mathrm{N} 2 \text {-rock }}$ between observed values and theoretical values of metamorphic devolatilization calculated by Rayleigh fractionation modeling (A-C), and increase in $\delta^{15} \mathrm{~N}$ of $\mathrm{N}_{2}$

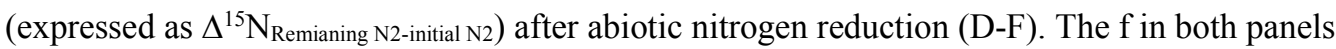
denote the fraction of remaining nitrogen in the reactant. See text for discussion.

Fig. 5. Diagram showing steady decrease in the $\delta^{15} \mathrm{~N}$ value of $\mathrm{N}_{2}$ from one single borehole at 2.4 km below surface of the Kidd Creek mine over a 10-year period. 


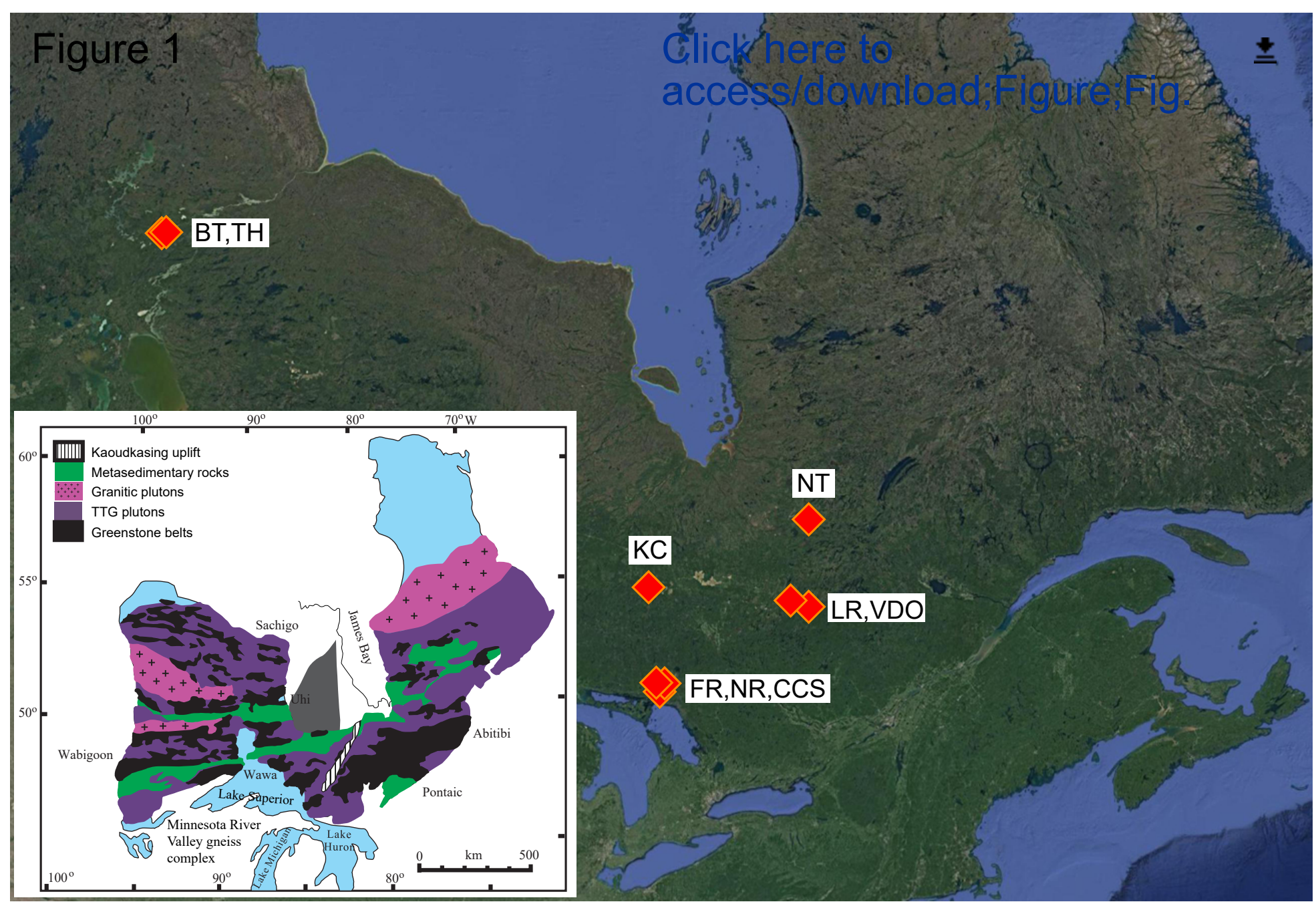


Figure 2

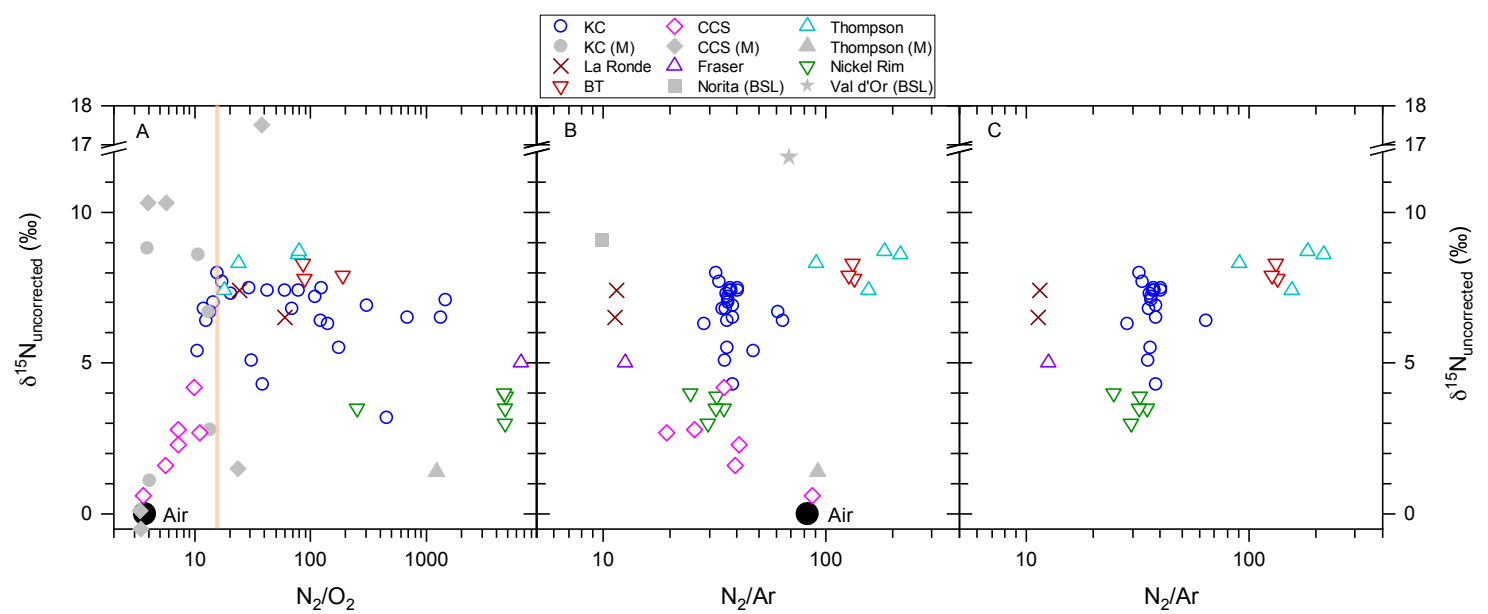


Figure 3

Click here to access/download;Figure;Fig. 3.pdf $\underline{\underline{ }}$

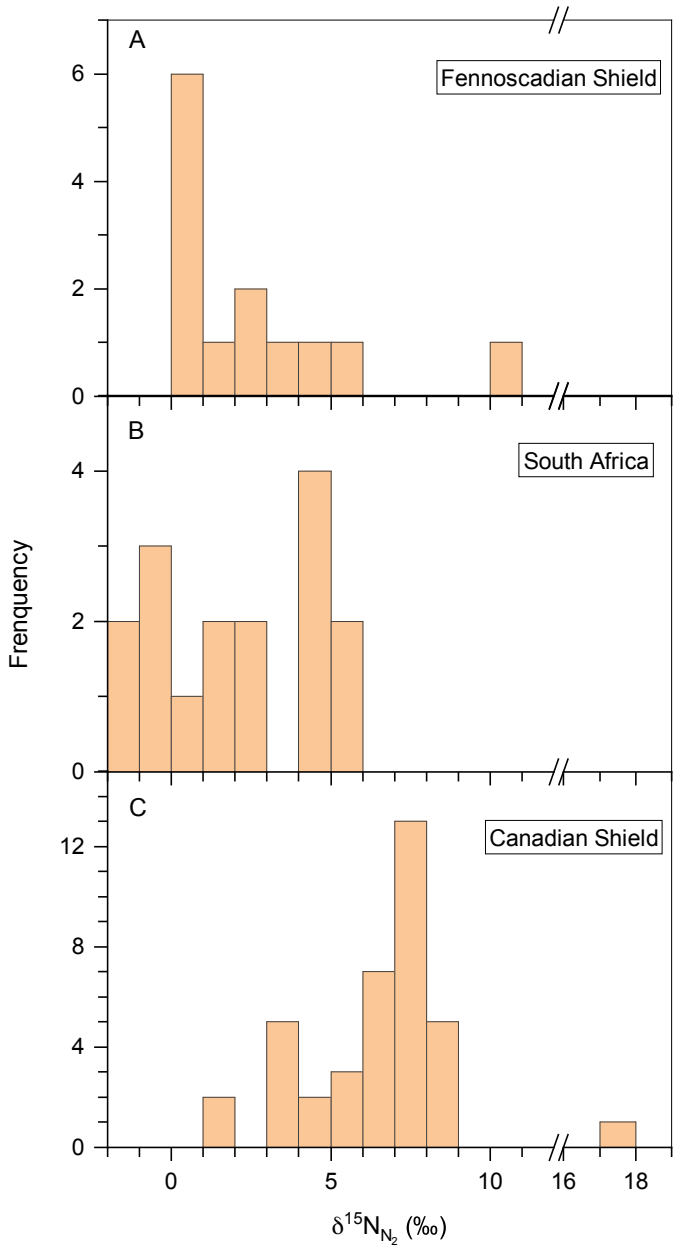


Figure 4

Click here to access/download;Figure;Fig. 4.pdf $\underline{\underline{ }}$

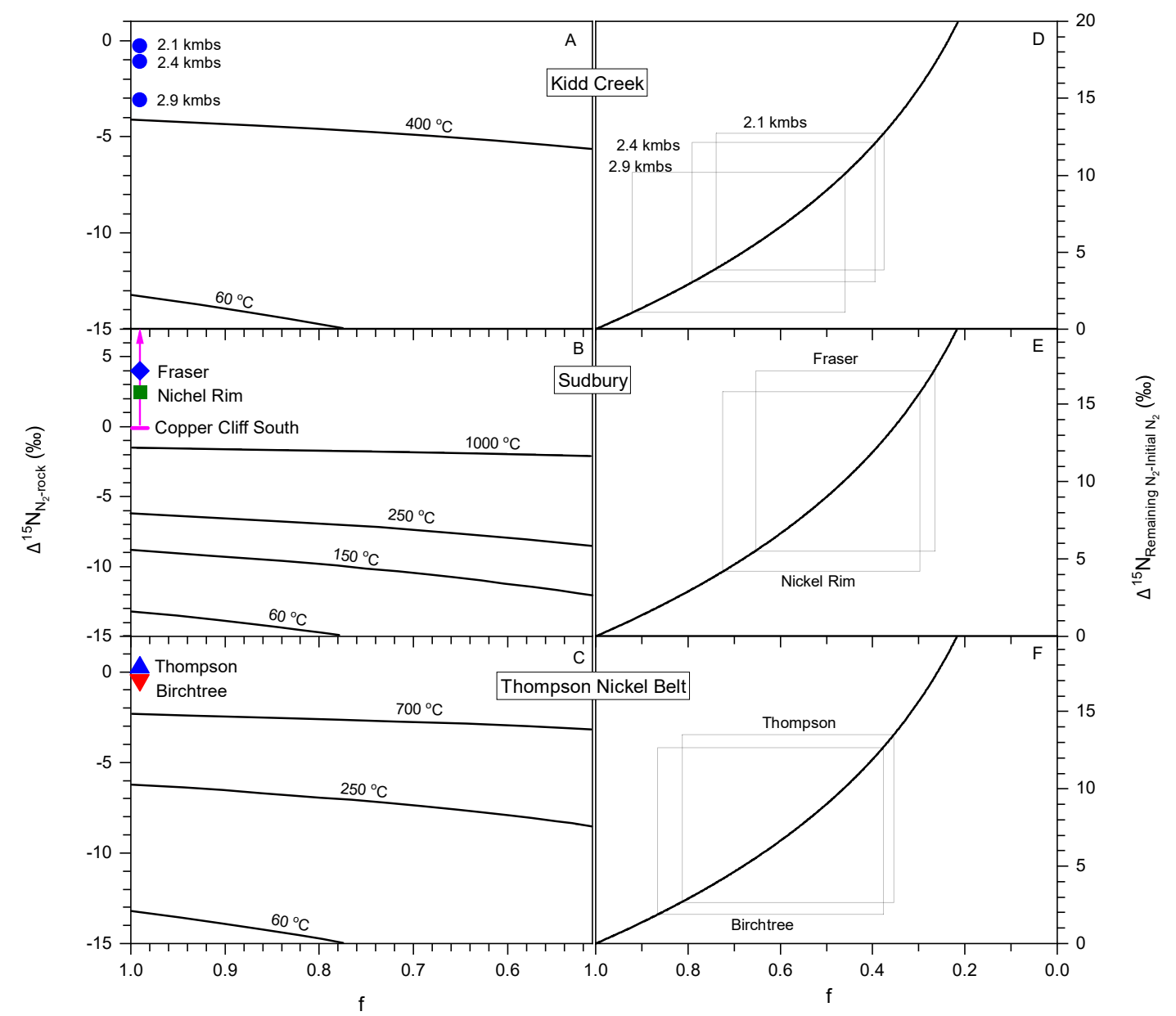


Figure 5

Click here to access/download;Figure;Fig. 5.pdf $\underline{\underline{ }}$

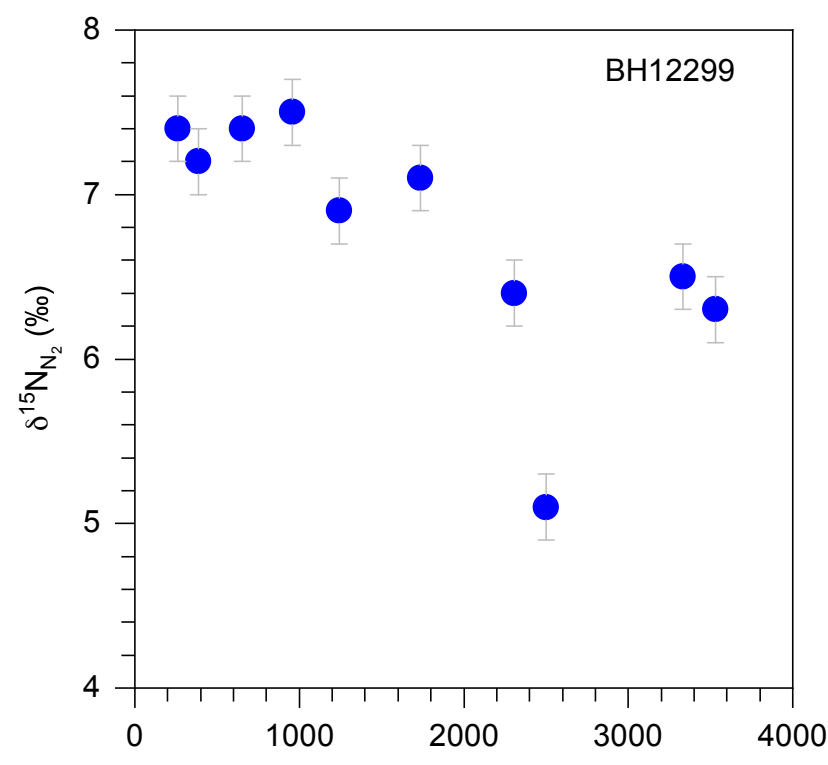

Days since drilling completion 


\begin{tabular}{|c|c|c|}
\hline 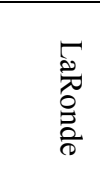 & $\begin{array}{l}\text { Pि } \\
\stackrel{0}{0} \\
\frac{0}{\pi}\end{array}$ & 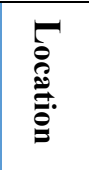 \\
\hline 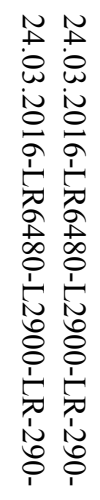 & 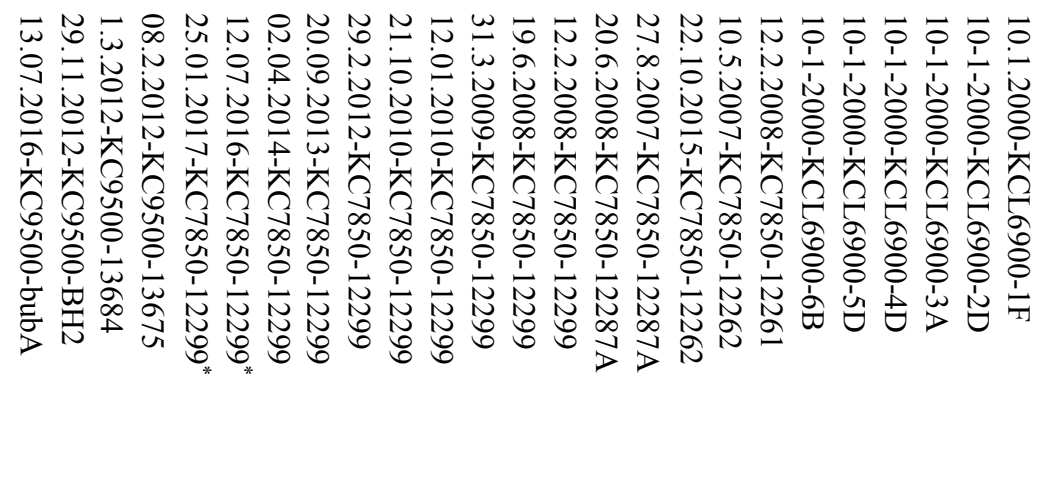 & 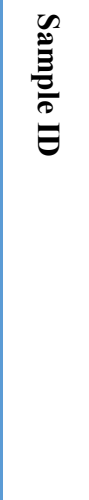 \\
\hline$\dot{\omega} \dot{\omega} \dot{\omega}$ & 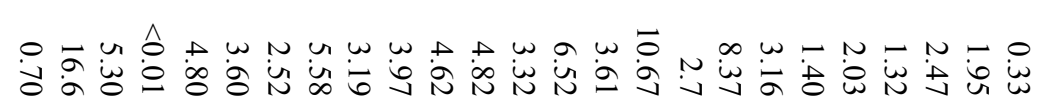 & 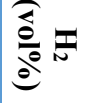 \\
\hline ï. & 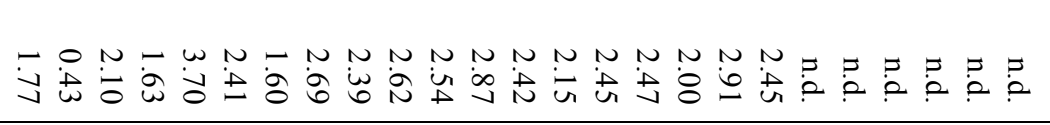 & $\frac{\widehat{\partial}}{\partial} \frac{\pi}{\partial}$ \\
\hline$\stackrel{\circ}{i} \underset{\omega}{i}$ & 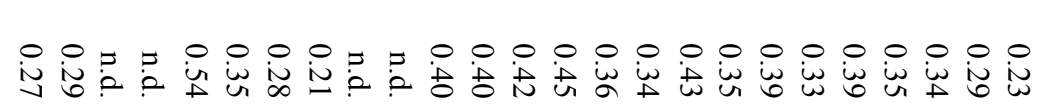 & $\frac{\partial}{\partial}$ \\
\hline$\dot{0} \dot{\dot{s}}$ & 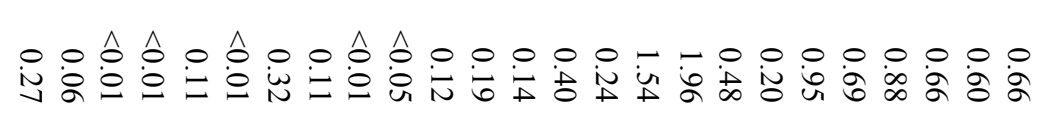 & $\frac{\partial}{\partial} 0$ \\
\hline N. & 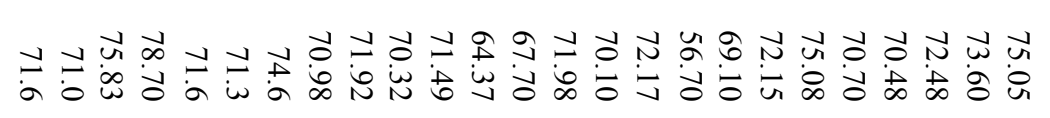 & $\stackrel{\partial}{\partial}$ \\
\hline 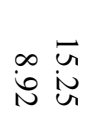 & 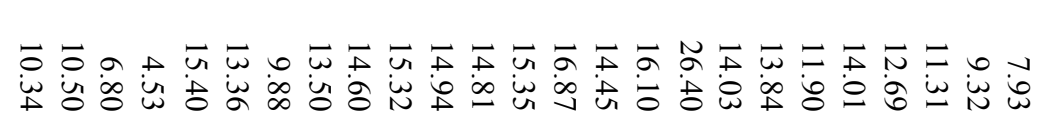 & $\frac{\widehat{\partial}}{e^{\circ}}$ \\
\hline $\begin{array}{l}\text { U⿺ } \\
\text { in }\end{array}$ & 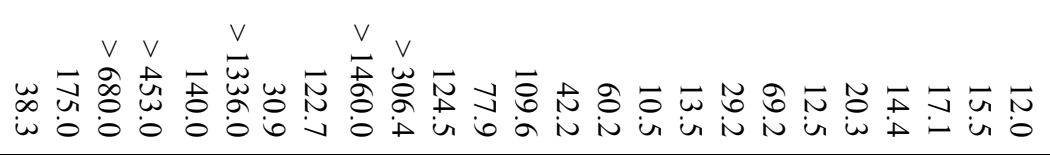 & 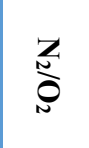 \\
\hline$\vec{i} \bar{i}$ & 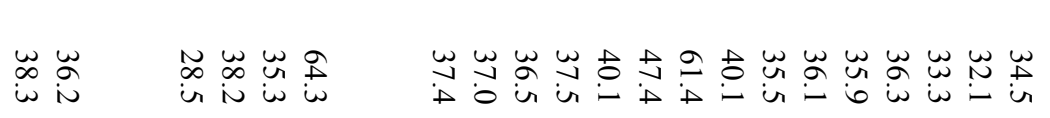 & $\underbrace{3}_{\frac{1}{3}}$ \\
\hline is $\vec{A}$ & 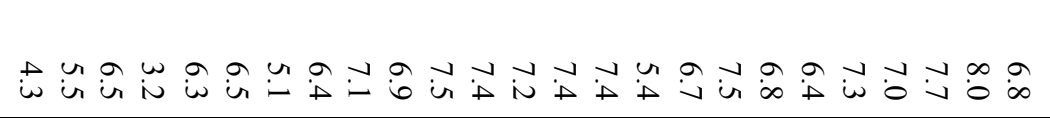 & 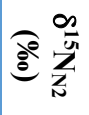 \\
\hline
\end{tabular}

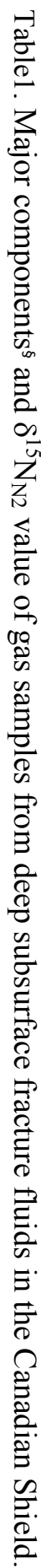




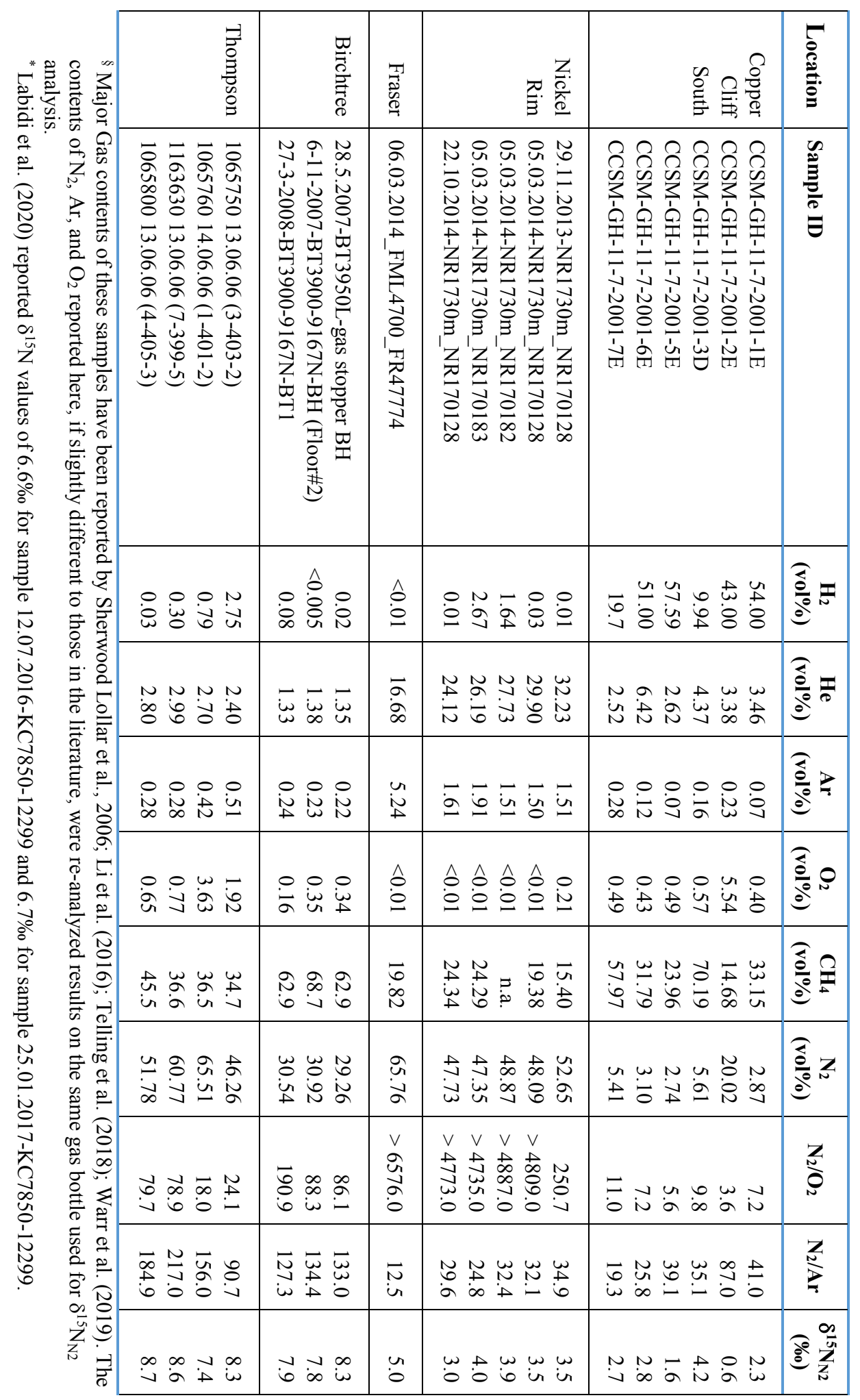




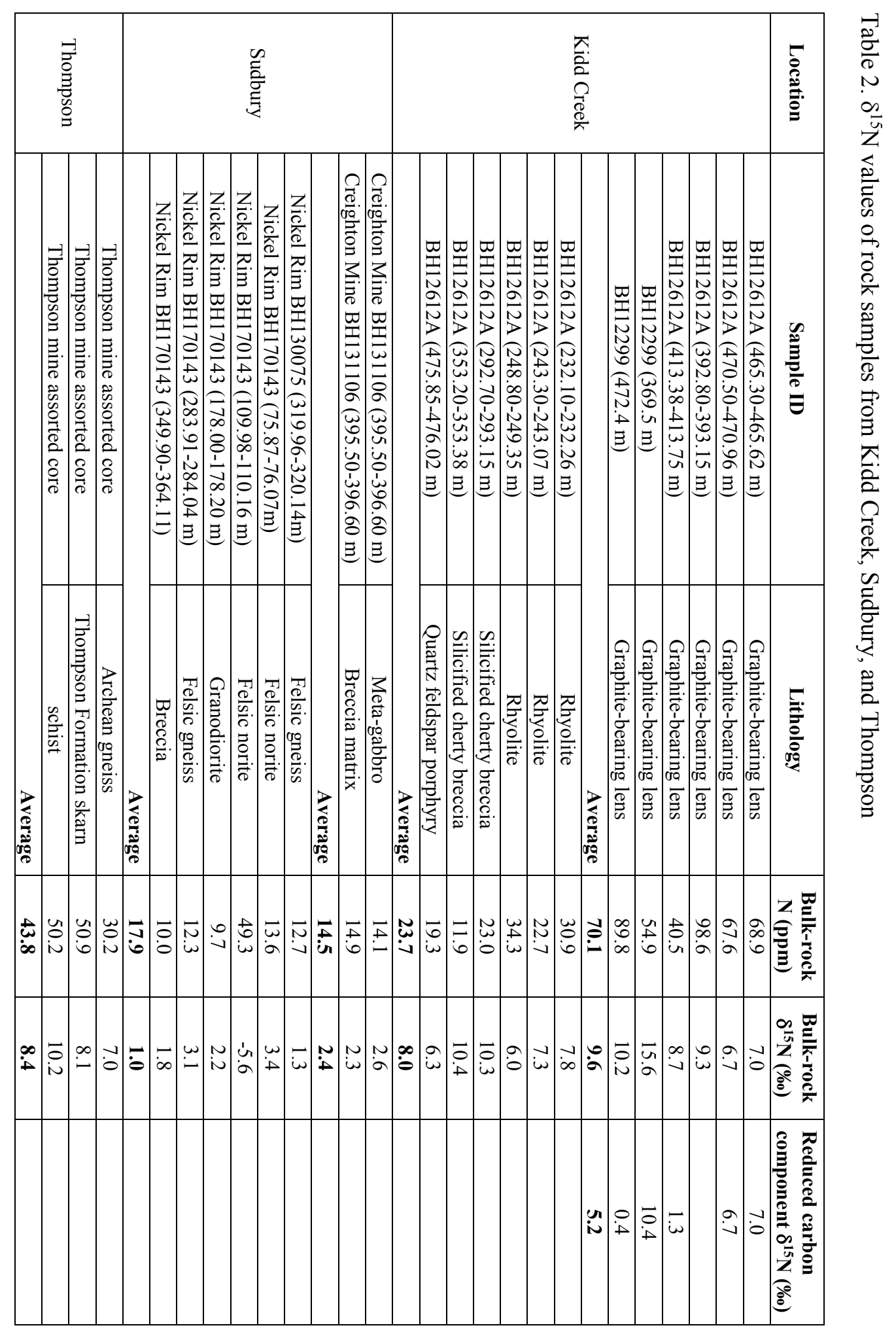

